\title{
Methods for Molecular Diagnosis of Human Prion Disease
}

Jonathan D. F. Wadsworth, Gary Adamson, Susan Joiner, Lara Brock, Caroline Powell, Jacqueline M. Linehan, Jonathan A. Beck, Sebastian Brandner, Simon Mead and John Collinge

MRC Prion Unit and Department of Neurodegenerative Disease, UCL Institute of Neurology, National Hospital for Neurology and Neurosurgery, Queen Square, London WC1N 3BG, UK

Correspondence should be addressed to J.D.F.W. (j.wadsworth@prion.ucl.ac.uk) 


\section{Summary}

Human prion diseases are associated with a range of clinical presentations, and they are classified by both clinicopathological syndrome and etiology, with subclassification according to molecular criteria. Here, we describe updated procedures that are currently used within the MRC Prion Unit to determine a molecular diagnosis of human prion disease. Sequencing of the $P R N P$ open reading frame to establish the presence of pathogenic mutations is described, together with detailed methods for immunoblot or immunohistochemical determination of the presence of abnormal prion protein in brain or peripheral tissues.

Key Words: Bovine spongiform encephalopathy; Creutzfeldt-Jakob disease; fatal familial insomnia; Gerstmann-Sträussler-Scheinker disease; kuru; prion; prion disease; prion protein; transmissible spongiform encephalopathy; variant Creutzfeldt-Jakob disease.

\section{Introduction}

Prion diseases are fatal neurodegenerative disorders that include Creutzfeldt-Jakob disease (CJD), Gerstmann-Sträussler-Scheinker disease (GSS), fatal familial insomnia (FFI), kuru, and variant CJD (vCJD) in humans (1-4). Their central feature is the posttranslational conversion of host-encoded, cellular prion protein $\left(\mathrm{PrP}^{\mathrm{C}}\right)$, to an abnormal isoform, designated $\operatorname{PrP}^{S c}(\mathbf{1}, 5)$. Human prion diseases are biologically unique in that the disease process can be triggered through inherited germline mutations in the human prion protein gene $(P R N P)$, infection (by inoculation, or in some cases by dietary 
exposure) with prion-infected tissue or by rare sporadic events that generate $\operatorname{PrP}^{\mathrm{Sc}}(\mathbf{1 - 3})$. Substantial evidence indicates that abnormal PrP isoforms are the principal, if not the sole, components of the transmissible infectious agent, or prion $(1,2,5)$. The existence of multiple strains or isolates of prions, has been difficult to accommodate within a protein only model of prion propagation; however, considerable experimental evidence suggests that prion strain diversity is encoded within PrP itself and that phenotypic diversity in human prion diseases relates to differing physicochemical properties of abnormal PrP isoforms (5-12). Furthermore, the propagation of distinct abnormal PrP isoforms may be determined by the host genome (13-15).

Human prion diseases are associated with a range of clinical presentations, and they are classified by both clinicopathological syndrome and etiology, with subclassification according to molecular criteria $(3,4,16-18)$. Approximately $85 \%$ of cases occur sporadically as Creutzfeldt-Jakob disease (sporadic CJD) at a rate of one to two cases per million population per year across the world, with an equal incidence in men and women $(2,19,20)$. Approximately $15 \%$ of human prion disease is associated with autosomal dominant pathogenic mutations in $P R N P$, and to date more than 40 mutations have been described $(2,18,21,22)$. These include insertions of between four and twelve extra repeats within the octapeptide repeat region between codons 51 and 91, a two-octapeptide repeat deletion (OPRD), and various point mutations causing missense or stop substitutions (Fig. 1). 
Although human prion diseases are transmissible diseases, acquired forms have, until recently, been confined to rare and unusual situations. The most frequent causes of iatrogenic CJD occurring through medical procedures have arisen as a result of treatment with growth hormone derived from human cadavers or implantation of dura mater grafts (23-25). Less frequent incidences of iatrogenic human prion disease have resulted from transmission of CJD prions during corneal transplantation, contaminated electroencephalographic electrode implantation, and surgical operations using contaminated instruments or apparatus (25). The most well-known example of acquired prion disease in humans is kuru, which was transmitted by cannibalism among the Fore and neighboring linguistic groups of the Eastern Highlands in Papua New Guinea (17, 26-28). Remarkably, kuru demonstrates that incubation periods of infection with human prions can exceed 50 years (28). The appearance of VCJD in the United Kingdom from 1995 onward (29), and the experimental confirmation that this is caused by the same prion strain as that causing bovine spongiform encephalopathy (BSE) in cattle $(7,14,30$, 31), has led to widespread concern that exposure to the epidemic of BSE poses a distinct threat to public health in the United Kingdom and other countries $(3,32)$. The extremely prolonged and variable incubation periods of these diseases, particularly when crossing a transmission barrier $(\mathbf{3}, \mathbf{3 3})$, means that it will be many years before the full consequences of human exposure to bovine prions can be predicted with confidence. In the meantime, significant numbers in the population may be incubating this disease (34) and pose a risk for transmitting infection to others via blood transfusion, blood products, tissue and organ transplantation, and other iatrogenic routes $(32,35-39)$. 
Polymorphism at codon 129 of $P R N P$ (Fig. 2) (encoding either methionine [M] or valine [V]) powerfully affects susceptibility to human prion diseases (20, 27, 40-44). About $38 \%$ of northern Europeans are homozygous for the more frequent methionine allele, $51 \%$ are heterozygous, and $11 \%$ homozygous for valine. Homozygosity at PRNP codon 129 predisposes to the development of sporadic and acquired CJD $(20,27,40-43)$, and is most strikingly observed in vCJD where all pathologically proven cases studied so far have been homozygous for codon 129 methionine of $\operatorname{PRNP}(\mathbf{3}, \mathbf{3 8}, \mathbf{4 4 - 4 6 )}$. One heterozygous patient thought clinically to have vCJD did not have an autopsy examination (47). Heterozygosity at codon 129 is thought to confer resistance to prion disease by inhibiting homologous protein-protein interactions essential for efficient prion replication while the presence of methionine or valine at residue 129 controls the propagation of distinct human prion strains via conformational selection $(3,5,32,45$, 46).

The clinical presentation of human prion disease varies enormously, and there is considerable overlap observed between individuals with different disease etiologies (3, $19,22)$ and even in family members with the same pathogenic PRNP mutation (21, 22, 48-52). Progressive dementia, cerebellar ataxia, pyramidal signs, chorea, myoclonus, extrapyramidal features, pseudobulbar signs, seizures, and amyotrophic features can be seen in variable combinations. Criteria used for diagnosis of human prion disease are available $(3,53)$, and definite diagnosis of sporadic and acquired prion disease relies upon neuropathological examination and the demonstration of abnormal PrP deposition in the central nervous system by either immunoblotting or immunohistochemistry. In the 
appropriate clinical setting, identification of a pathogenic PRNP mutation provides clear diagnosis of inherited prion disease and subclassification according to mutation; PRNP analysis is also used for presymptomatic genetic testing in affected families $(3,17,18$, $22,48,54,55)$. Because of the extensive phenotypic variability seen in inherited prion disease and its ability to mimic other neurodegenerative conditions, notably Alzheimer's disease, $P R N P$ analysis should be considered in all patients with undiagnosed dementing and ataxic disorders $(3,22,49)$. In addition, we have recently described a novel clinical and pathological phenotype associated with a Y163X mutation in $P R N P$, a prion protein systemic amyloidosis, characterised by slow disease progression, diarrhoea, autonomic failure and neuropathy (56). This newly recognised novel disease phenotype indicates that $P R N P$ analysis should also be considered in the investigation of unexplained chronic diarrhoea associated with a neuropathy or an unexplained syndrome similar to familial amyloid polyneuropathy.

Clinicians are fortunate that a range of sensitive and specific investigations are available to secure a diagnosis in life. Principal amongst these is magnetic resonance imaging (MRI) of the brain which shows increased signal on T2 or diffusion weighted images in the cerebral cortex, basal ganglia and thalamus in $>80 \%$ of patients with sporadic CJD $(57,58)$, although these are sometimes overlooked (59). Cerebrospinal fluid (CSF) analysis is also helpful for differential diagnosis as the absence of a raised cell count or oligoclonal bands are reassuring from the point of view of inflammatory aetiologies. Raised CSF proteins 14-3-3, S100b and NSE are also found in $\sim 90 \%$ sporadic CJD 
patients although their presence is not specific for the disease. CSF PrP amplification technologies show promise as specific and sensitive confirmatory tests $(\mathbf{6 0}, \mathbf{6 1})$.

The brains of patients with prion disease frequently show no recognizable abnormalities on gross examination at necropsy; however, microscopic examination of the brain at either necropsy or in ante-mortem biopsy specimens typically reveals characteristic histopathologic changes, consisting of neuronal vacuolation and degeneration, which gives the cerebral gray matter a microvacuolated or "spongiform" appearance accompanied by a reactive proliferation of astroglial cells (62-64). Although spongiform degeneration is frequently detected, it is not an obligatory neuropathologic feature of prion disease; astrocytic gliosis, although not specific to the prion diseases, is more constantly seen. The lack of a lymphocytic inflammatory response is also an important characteristic. Demonstration of abnormal PrP immunoreactivity, or more specifically biochemical detection of $\operatorname{PrP}^{\mathrm{Sc}}$ in brain material by immunoblotting techniques is diagnostic of prion disease and some forms of prion disease are characterized by deposition of amyloid plaques composed of insoluble aggregates of $\operatorname{PrP}$ (62-65). Amyloid plaques are a notable feature of kuru and GSS $(62,65,66)$, but they are less frequently found in the brains of patients with sporadic CJD, which typically show a diffuse pattern of abnormal PrP deposition $(9,62,65)$. The histopathological features of vCJD are remarkably consistent and distinguish it from other human prion diseases, with large numbers of PrP-positive amyloid plaques that differ in morphology from the plaques seen in kuru and GSS in that the surrounding tissue takes on a microvacuolated appearance, giving the plaques a florid appearance $(29,67)$. The tissue distribution of $\mathrm{PrP}^{\mathrm{Sc}}$ in vCJD 
differs strikingly from that in classical CJD with uniform involvement of lymphoreticular tissues $(35,68-72)$. Depending upon the density of lymphoid follicles, $\mathrm{PrP}^{\mathrm{Sc}}$ concentrations in vCJD peripheral tissues can vary enormously, with levels relative to brain as high as $10 \%$ in tonsil $(35,68)$ or as low as $0.002 \%$ in rectum $(35,39)$. Tonsil biopsy is used for diagnosis of vCJD, and to date it has shown 100\% sensitivity and specificity for diagnosis of vCJD at an early clinical stage $(3,35,38,68)$, although some patients show scanty deposition of abnormal PrP and a large number of follicles may have to be examined by immunohistochemistry (73).

In this chapter, we update our previous contribution to Prion Protein Protocols (74) and describe the procedures that are currently used within the MRC Prion Unit to provide a molecular diagnosis of human prion disease. Methods for sequencing the PRNP open reading frame to establish the presence of pathogenic mutations and to determine $P R N P$ polymorphic codon 129 genotype are described together with procedures used for immunoblot or immunohistochemical determination of the presence of abnormal PrP in brain or peripheral tissues.

\section{Materials}

\subsection{Molecular Genetics}

1. BACC3 DNA extraction kit from GE Healthcare Life Sciences.

2. TE buffer: $10 \mathrm{mM}$ Tris and $1 \mathrm{mM}$ EDTA, $\mathrm{pH}$ 8.0.

3. MegaMix Royal (Microzone, Haywards Heath, UK).

4. HyperLadder 100bp (Bioline, London, UK). 
5. MicroClean (Microzone).

6. BigDye version 1.1 Cycle Sequencing kit (Applied Biosystems, Foster City, CA).

7. BetterBuffer (Microzone).

8. 0.5 M EDTA, pH 8.0, diluted fourfold in water.

9. Hi-Di formamide (Applied Biosystems).

10. Performance-optimized polymer 7 (Applied Biosystems).

11. DdeI restriction endonuclease, including NEBuffer 3 (New England Biolabs, Ipswich, MA).

12. MetaSieve agarose (Flowgen, Ashby, Leicestershire, UK).

13. PflFI restriction endonuclease, including NEBuffer 4 (New England Biolabs).

14. BsaI restriction endonuclease, including NEBuffer 3 (New England Biolabs).

15. TOPO TA cloning kit for sequencing (Invitrogen, Paisley, UK).

16. Luria-Bertani (LB) broth.

17. TaqMan GTXpress Master Mix (Life Technologies, Paisley, UK).

18 TaqMan MGB probes (Life Technologies, Paisley, UK).

\subsection{Immunoblotting}

1. Dulbecco's sterile phosphate-buffered saline (PBS) lacking $\mathrm{Ca}^{2+}$ and $\mathrm{Mg}^{2+}$ ions.

2. Duall tissue grinders (Anachem Ltd., Luton, Bedfordshire, UK).

3. Proteinase K (specific enzymatic activity $\sim 30$ Anson units/g) prepared as a stock solution of $1 \mathrm{mg} / \mathrm{ml}$ in water.

4. Sodium dodecyl sulfate (SDS) sample buffer. 
a. A stock concentrate of $2 \times$ SDS sample buffer [142 mM Tris, $22.72 \%(\mathrm{v} / \mathrm{v})$ glycerol, $4.54 \%$ (w/v) SDS, and $0.022 \%(\mathrm{w} / \mathrm{v})$ bromphenol blue] is prepared in water and titrated to $\mathrm{pH} 6.8$ with $\mathrm{HCl}$.

b. This solution requires adjustment with reducing agent and proteinase $\mathrm{K}$ inhibitor immediately before use to produce $2 \times$ working SDS sample buffer.

c. For preparation of $0.5 \mathrm{ml}$ of $2 \times$ working SDS sample buffer, mix the following: $440 \mu \mathrm{l}$ of stock concentrate of $2 \times$ SDS sample buffer plus $20 \mu \mathrm{l}$ of 2-mercaptoethanol plus $40 \mu \mathrm{l}$ of $100 \mathrm{mM}$ 4-(2-aminoethyl)-benzene sulfonyl fluoride prepared in water.

d. This produces $2 \times$ working SDS sample buffer of the following final composition: $125 \mathrm{mM}$ Tris-HCl, 20\% (v/v) glycerol, $\mathrm{pH}$ 6.8, containing 4\% (w/v) SDS, 4\% (v/v) 2-mercaptoethanol, 8 mM 4-(2aminoethyl)benzenesulfonyl fluoride, and $0.02 \%$ (w/v) bromphenol blue.

5. Novex® 16\% Tris-glycine SDS-polyacrylamide gel electrophoresis (PAGE) gels (Life Technologies Ltd, Paisley, UK).

6. Seeblue prestained molecular mass markers (Life Technologies Ltd).

7. SDS-PAGE electrophoresis buffer: $100 \mathrm{ml}$ of $10 \times$ Tris-glycine, SDS concentrate [0.25 M Tris, 1.92 M glycine, 1\% (w/v) SDS (National Diagnostics, USA)] plus $900 \mathrm{ml}$ water. 
8. Immobilon P transfer membrane.

9. Electroblotting buffer: $100 \mathrm{ml}$ of $10 \times$ Tris-glycine concentrate [0.25 M Tris and 1.92

M glycine (National Diagnostics, USA)], $700 \mathrm{ml}$ of water, and $200 \mathrm{ml}$ of methanol.

10. PBST: $100 \mathrm{ml}$ of 10× PBS concentrate (low in phosphate) (VWR, Lutterworth, UK), $900 \mathrm{ml}$ of water, and $0.5 \mathrm{ml}$ of Tween-20.

11. Anti-PrP monoclonal antibody 3F4 (Covance, Princeton, New Jersey).

12. Goat anti-mouse $\operatorname{IgG}$ (fab-specific) alkaline phosphatase conjugate (absorbed with human serum proteins) (Sigma-Aldrich Poole, Dorset, UK).

13. CDP-star chemiluminescent substrate (Life Technologies Ltd).

14. Carestream Biomax MR film (Anachem Ltd).

15. AttoPhos chemifluorescent substrate (Promega, Madison, WI).

a. Mix $36 \mathrm{mg}$ of Attophos substrate in $60 \mathrm{ml}$ of Attophos buffer.

b. Store as $3 \mathrm{ml}$ aliquots at $-20^{\circ} \mathrm{C}$.

16. Sodium lauroylsarcosine (Merk Chemicals Ltd, Nottingham, UK).

17. Benzonase (Benzon nuclease purity 1 [25 U/ $\mu \mathrm{l}$ ], Merck Chemicals Ltd).

18. Sodium phosphotungstic acid stock solution.

a. Stock solution is $4 \%(\mathrm{w} / \mathrm{v})$ sodium phosphotungstic acid containing $170 \mathrm{mM}$ $\mathrm{MgCl}_{2}$ prepared in water, $\mathrm{pH} 7.4$.

b. For preparation of $10 \mathrm{ml}$ of stock solution, add $0.4 \mathrm{~g}$ of sodium phosphotungstic acid and $0.35 \mathrm{~g} \mathrm{MgCl}_{2} \cdot 6 \mathrm{H}_{2} \mathrm{O}$ to a $50 \mathrm{ml}$ polypropylene tube and make to $\sim 9 \mathrm{ml}$ with water.

c. The $\mathrm{pH}$ of this solution is acidic and needs to be titrated with $5 \mathrm{M} \mathrm{NaOH}$ to $\mathrm{pH} 7.4$ before adjusting to a final volume of $10 \mathrm{ml}$ with water. 
d. On addition of $\mathrm{NaOH}$, immediate formation of insoluble $\mathrm{MgOH}_{2}$ occurs that will redissolve on vortexing.

e. Addition of $5 \mathrm{M} \mathrm{NaOH}$ followed by vortexing and measurement of $\mathrm{pH}$ needs to be done repetitively.

f. For $10 \mathrm{ml}$ of stock solution, addition of $360 \mu \mathrm{l}$ of $5 \mathrm{M} \mathrm{NaOH}$ will generate $\mathrm{pH}$ 7.4 .

\subsection{Immunohistochemistry}

\subsubsection{Procurement}

1. $10 \%$ buffered formal-saline.

2. Biopsy cassettes (R. A. Lamb, Eastbourne, UK).

\subsubsection{Prion Deactivation with Formic Acid}

1. Biopsy cassettes (R. A. Lamb).

2. $98 \%$ formic acid.

3. $2 \mathrm{M}$ sodium hydroxide: $80 \mathrm{~g}$ of sodium hydroxide pellets in water to 1 liter.

4. $10 \%$ buffered formal-saline.

\subsubsection{Tissue Processing}

1. $10 \%$ buffered formal-saline.

2. Industrial methylated spirits (J.M. Loveridge Ltd., Southampton, UK), diluted in water to desired concentration.

3. Xylene. 
4. Pure paraffin wax (R A Lamb).

\subsubsection{Tissue Sectioning}

1. Microtome (Leica, Wetzlar, Germany).

2. SuperFrost microscope slides (VWR, West Chester, PA).

\subsubsection{Tissue Staining}

1. Xylene.

2. Absolute ethanol diluted in water to desired concentration.

3. Harris hematoxylin (BDH).

4. Acid alcohol: $1 \% \mathrm{HCl}$ in absolute ethanol.

5. Eosin Y solution $0.5 \%$, aqueous (VWR).

6. Pertex mounting medium (Cox Scientific Ltd, Kettering, UK.).

7. Benchmark staining machine (Ventana Medical Systems, Illkirch CEDEX, France).

8. Protease 1 (Ventana Medical Systems).

9. Rabbit anti-glial fibrillary protein (Dako UK Ltd., Ely, Cambridgeshire, UK); antibody diluent (Ventana Medical Systems).

10. IViewDAB detection kit (Ventana Medical Systems), containing an inhibitor solution (3\% hydrogen peroxide) (4 min), universal biotinylated secondary antibody (10 min), streptavidin-horseradish peroxidase solution (10 $\mathrm{min})$, 3,3-diaminobenzidine and hydrogen peroxide (20 min), copper solution (4 min).

11. Hematoxylin (Ventana Medical Systems).

12. Bluing reagent (Ventana Medical Systems). 
13. Tris-EDTA-citrate buffer, $\mathrm{pH}$ 7.8: $2.1 \mathrm{mM}$ Tris, $1.3 \mathrm{mM}$ EDTA, and $1.1 \mathrm{mM}$ sodium citrate.

14. $98 \%$ formic acid.

15. $10 \mathrm{mM}$ sodium citrate buffer, $\mathrm{pH}$ 6.0: solution A: $10.5 \mathrm{~g}$ of citric acid in $500 \mathrm{ml}$ of deionized water and solution B: $29.41 \mathrm{~g}$ of sodium citrate in $1000 \mathrm{ml}$ of water.

a. Add $18 \mathrm{ml}$ of solution $\mathrm{A}$ to $82 \mathrm{ml}$ of solution $\mathrm{B}$, and then adjust to 1 liter final volume with water.

16. Anti-PrP monoclonal antibody ICSM35 (D-Gen Ltd., London, UK).

17. Protease 3 (Ventana Medical Systems).

18. Superblock (Pierce Chemical, Rockford, IL).

19. Prepared with methanol GPR and 30\% hydrogen peroxide.

20. Tris-buffered saline (TBS): $50 \mathrm{mM}$ Tris, $145 \mathrm{mM} \mathrm{NaCl}$, pH 7.6.

a. For 1 liter of $10 \times$ stock, add $60.5 \mathrm{~g}$ of Trizma base and $84.7 \mathrm{~g}$ of sodium chloride to $800 \mathrm{ml}$ of water.

b. Adjust to $\mathrm{pH} 7.6$ with $32.00 \mathrm{ml}$ of concentrated $\mathrm{HCl}$.

c. Make to 1 liter final volume with water.

d. Dilute $10 \times$ TBS to $1 \times$ concentration with water.

21. $4 \mathrm{M}$ guanidine thiocyanate.

a. Add $472.64 \mathrm{~g}$ guanidine thiocyanate in water to a final volume of 1 liter.

22. Normal rabbit serum (Dako UK Ltd.).

23. Biotinylated rabbit anti-mouse immunoglobulins (Dako UK Ltd.).

24. Strept ABComplex/HRP Duet kit (Dako UK Ltd.).

25. 3,3-diaminobenzidine tetrachloride. 
a. Use at a final concentration of $25 \mathrm{mg}$ in $100 \mathrm{ml}$ of $1 \times \mathrm{TBS}$.

\section{Methods}

\subsection{Molecular Genetics}

\subsubsection{Isolation of Genomic DNA from Blood}

1. All procedures are performed within a class 1 microbiological safety cabinet situated within an ACDP level II containment laboratory with strict adherence to local rules of safe working practice. Informed consent for the analysis of a sample must be established before investigation. This may be obtained from the patient (or next of kin or other advocate in accordance with the Mental Capacity Act 2005 in the UK). For predictive testing, we expect evidence of appropriate genetic counselling before analysis.

2. Genomic DNA is extracted from whole anticoagulated blood (typically from a 5-ml EDTA tube) by using the Nucleon BACC3 DNA extraction kit (see Subheading 2.1., item 1) following the manufacturer's instructions. DNA concentrations are determined using a Nanodrop ND-1000 spectrophotometer, and adjusted to $200-250 \mathrm{ng} / \mu \mathrm{l}$ in TE buffer (see Subheading 2.1., item 2). Concentrations are re-measured before dilution of DNA in TE buffer to a final concentration of $20 \mathrm{ng} / \mu \mathrm{l}$ and storage at $4^{\circ} \mathrm{C}$.

\subsubsection{Sequencing of PRNP Open Reading Frame}

\subsubsection{PCR of PRNP Open Reading Frame}

1. Prepare a premix of MegaMix Royal (a 2x concentrate, see Subheading 2.1., item 3) containing primers at $0.5 \mu \mathrm{M}$ sufficient for $25-\mu \mathrm{l}$ reactions on a $96-$ well plate. PCR 
primers used to amplify the open reading frame are 5'-CTA TGC ACT CAT TCA TTA TGC-3' (forward) and 5'-GTT TTC CAG TGC CCA TCA GTG-3' (reverse). Use $12.5 \mu \mathrm{l}$ MegaMix Royal and make each reaction up to $25 \mu \mathrm{l}$ using water and primers.

2. Add $1 \mu \mathrm{l}$ of $20 \mathrm{ng} / \mu \mathrm{l}$ genomic DNA.

3. Thermal cycling is performed on an MJ Research (Watertown, MA) Tetrad 1 PCR machine or similar using the following cycling parameters:
a. $95{ }^{\circ} \mathrm{C}$ for $5 \mathrm{~min}$.
b. $95{ }^{\circ} \mathrm{C}$ for $30 \mathrm{~s}$.
c. $58{ }^{\circ} \mathrm{C}$ for $40 \mathrm{~s}$.
d. $72{ }^{\circ} \mathrm{C}$ for $1 \mathrm{~min}$.
e. repeat steps $\mathrm{b}-\mathrm{d}$ an additional 34 times.

4. Assess polymerase chain reaction (PCR) by electrophoresis of $5 \mu \mathrm{l}$ of product on a $2 \%$ ethidium bromide-stained agarose gel with $5 \mu$ of HyperLadder IV (see Subheading 2.1., item 4) size standard. The gel is viewed using a Gel Doc 1000 transilluminator (BioRad, Hemel Hempstead, UK) and Quantity One 4.5.1 software or similar.

\subsubsection{PCR Product Cleanup}

1. An equal volume of MicroClean (see Subheading 2.1., item 5)

is added to the PCR product and mixed well by pipetting or vortexing.

2. The mixture is left at room temperature for $15 \mathrm{~min}$.

3. The plate is centrifuged at $2,000-4,000 \mathrm{~g}$ for $40 \mathrm{~min}$ at room temperature. 
4. The supernatant is removed by centrifuging the plate at $40 \mathrm{~g}$ for $30 \mathrm{~s}$ in an inverted position on tissue paper by using centrifuge plate holders.

5. Resuspend the cleaned PCR product in $150 \mu$ of water.

\subsubsection{Sequencing Reactions}

1. For each sequencing reaction, prepare a premix of $1 \mu$ of BigDye (see Subheading 2.1., item 6), $5 \mu \mathrm{l}$ of BetterBuffer (see Subheading 2.1., item 7), $0.75 \mu \mathrm{l}$ of sequencing primer at $5 \mathrm{pmol} / \mu \mathrm{l}$, approximately $2.5 \mathrm{ng}$ of cleaned PCR product, and water to a final volume of $15 \mu \mathrm{l}$. The amount of PCR product is estimated using visual comparison with known amounts of HyperLadder IV (see Subheading 2.1., item 4) size standard. 2. Sequencing primers are 5'-GAC GTT CTC CTC TTC ATT TT-3' (forward 1), 5'-CCG AGT AAG CCA AAA ACC AAC-3' (forward 2), and 5'-CAC CAC CAC TAA AAG GGC TGC-3' (reverse 1), 5'-TTC ACG ATA GTA ACG GTC C-3' (reverse 2).

3. Sequencing reactions are thermally cycled on an MJ Research Tetrad 1 PCR machine or similar using the following cycling parameters:
a. $96^{\circ} \mathrm{C}$ for $1 \mathrm{~min}$.
b. $96^{\circ} \mathrm{C}$ for $10 \mathrm{~s}$.
c. $50^{\circ} \mathrm{C}$ for $5 \mathrm{~s}$.
d. $60^{\circ} \mathrm{C}$ for $4 \mathrm{~min}$.
e. Repeat steps b-d 24 times.

\subsubsection{Sequencing Product Cleanup}


1. To each sequencing reaction, add $3.75 \mu$ of $0.125 \mathrm{M}$ EDTA, pH 8.0 (see Subheading

\section{1., item 8).}

2. Add $45 \mu \mathrm{l}$ of $100 \%$ ethanol to each reaction and mix by pipetting.

3. Leave reactions at room temperature for $15 \mathrm{~min}$.

4. Centrifuge the plate at $3,000 \mathrm{~g}$ for $30 \mathrm{~min}$ at $4^{\circ} \mathrm{C}$.

5. The supernatant is removed by centrifuging the plate at $185 \mathrm{~g}$ for $1 \mathrm{~min}$ in an inverted position on tissue paper.

6. Add $50 \mu \mathrm{l}$ of $70 \%$ ethanol in water.

7. Centrifuge the plate at $1,650 \mathrm{~g}$ for $15 \mathrm{~min}$ at $4{ }^{\circ} \mathrm{C}$.

8. The supernatant is removed by centrifuging the plate at $185 \mathrm{~g}$ for $1 \mathrm{~min}$ in an inverted position on tissue paper.

9. Place the plate on the PCR block held at $37^{\circ} \mathrm{C}$ for 5 min to remove final traces of ethanol.

\subsubsection{Electrophoresis}

1. Add $10 \mu$ of Hi-Di formamide loading solution (see Subheading 2.1., item 9) and vortex the plate for $30 \mathrm{~s}$.

2. Denature the samples by placing on the PCR block held at $95^{\circ} \mathrm{C}$ for 2 min and then immediately transfer to ice.

3. Standard run conditions are applied to electrophoresis of sequencing products on an Applied Biosystems 3730xl, using polymer POP7 (see Subheading 2.1., item 10), 50-cm arrays, and a standard run module with a sample injection time of $15 \mathrm{~s}$. 


\subsubsection{Data Analysis}

1. Data analysis is performed using Applied Biosystems Seqscape software version 2.5. 2. Analysis filter settings are adjusted to allow assembly of poor data due to insertions or deletions (maximum mixed bases 95\%, maximum Ns 95\%, minimum clear length bp of 1 , and minimum sample score of 1$)$.

3. Poor data or failed reactions are removed from projects by visual inspection of data.

\subsubsection{PCR Size Fractionation to Investigate Insertion or Deletion Variants}

1. Prepare a premix of Mega Mix Blue (see Subheading 2.1., item 3) containing primers at $0.5 \mu \mathrm{M}$ sufficient for $25-\mu 1$ reactions on a $96-$ well plate. PCR primers are 5'-GAC CTG GGC CTC TGC AAG AAG CGC-3' (forward) and 5'-GGC ACT TCC CAG CAT GTA GCC G-3' (reverse).

2. Add $1 \mu \mathrm{l}$ of $20 \mathrm{ng} / \mu \mathrm{l}$ genomic DNA.

3. Thermal cycling is performed on an MJ Research Tetrad 1 PCR machine or similar using the following cycling parameters:
a. $94^{\circ} \mathrm{C}$ for $5 \mathrm{~min}$.
b. $94^{\circ} \mathrm{C}$ for $30 \mathrm{~s}$.
c. $65^{\circ} \mathrm{C}$ for $30 \mathrm{~s}$.
d. $72^{\circ} \mathrm{C}$ for $1 \mathrm{~min}$.
e. Repeat steps b-d 34 times.
f. $72^{\circ} \mathrm{C}$ for $5 \mathrm{~min}$. 
4. Assess PCR by electrophoresis of $5 \mu \mathrm{l}$ of product on a $2 \%$ ethidium bromide-stained agarose gel with $5 \mu$ of HyperLadder IV (see Subheading 2.1., item 4) size standard. The gel is viewed using a Bio-Rad Gel Doc 1000 transilluminator and Quantity One 4.5.1 software or similar.

5. 1 OPRD and 6 OPRI controls are run on each gel (Fig. 3).

\subsubsection{Mutation Confirmation}

A second assay is performed to confirm the presence or absence of missense or stop mutations when a predictive genetic test is being carried out. PCR size fractionation, as described above, is sufficient in addition to sequencing when testing for insertion mutants in a predictive setting; however, unexpected or unknown insertion mutations may require cloning to confirm exact base pair composition. Examples of confirmatory assays used to detect the more common PRNP missense mutations and cloning methodology are described in Subheading 3.1.4.1.

\subsubsection{Confirmation of P102L}

1. Prepare a premix of MegaMix Blue (see Subheading 2.1., item 3) containing primers at $0.5 \mu \mathrm{M}$ sufficient for $25-\mu 1$ reactions on a $96-$ well plate. PCR primers are 5'-GAC CTG GGC CTC TGC AAG AAG CGC-3' (forward) and 5'-GGC ACT TCC CAG CAT GTA GCC G-3' (reverse).

2. Add $1 \mu \mathrm{l}$ of genomic DNA at $20 \mathrm{ng} / \mu \mathrm{l}$.

3. Thermal cycling is performed on an MJ Research Tetrad 1 PCR machine or similar using the following cycling parameters: 

a. $94^{\circ} \mathrm{C}$ for $5 \mathrm{~min}$.
b. $94^{\circ} \mathrm{C}$ for $30 \mathrm{~s}$.
c. $65^{\circ} \mathrm{C}$ for $30 \mathrm{~s}$.
d. $72^{\circ} \mathrm{C}$ for $1 \mathrm{~min}$.
e. Repeat steps b-d 34 times.
f. $72^{\circ} \mathrm{C}$ for $5 \mathrm{~min}$.

4. Prepare restriction endonuclease reaction by adding $10 \mu \mathrm{l}$ of PCR product, $1 \mu \mathrm{l}$ of DdeI (see Subheading 2.1., item 11), $2.5 \mu$ of 10× NEBuffer 3 (see Subheading 2.1., item 11), and $11.5 \mu$ of $\mathrm{H}_{2} \mathrm{O}$.

5. Incubate reaction at $37^{\circ} \mathrm{C}$ for $3 \mathrm{~h}$.

6. Electrophorese $10 \mu \mathrm{l}$ of digested PCR product on a 3\% 2:1 MetaSieve agarose (see Subheading 2.1., item 12) ethidium bromide-stained gel using $5 \mu$ l of HyperLadder IV (see Subheading 2.1., item 4) size standard. The gel is viewed using a Bio-Rad Gel Doc 1000 transilluminator and Quantity One 4.5.1 software.

7. Digested positive and negative controls are run on each gel to visualize mutant DNA (95-, 101-, and 152-bp) and wild-type DNA (101- and 247-bp) fragment patterns.

\subsubsection{D178N}

1. Prepare a premix of MegaMix Blue (see Subheading 2.1., item 3) containing primers at $0.5 \mu \mathrm{M}$ sufficient for $25-\mu 1$ reactions on a $96-$ well plate. PCR primers are 5'-CTA TGC ACT CAT TCA TTA TGC-3' (forward) and 5'-GTT TTC CAG TGC CCA TCA GTG-3' (reverse).

2. Add $1 \mu \mathrm{l}$ of genomic DNA at $20 \mathrm{ng} / \mu \mathrm{l}$. 
3. Thermal cycling is performed on an MJ Research Tetrad 1 PCR machine or similar using the following cycling parameters:
a. $94^{\circ} \mathrm{C}$ for $5 \mathrm{~min}$.
b. $94^{\circ} \mathrm{C}$ for $30 \mathrm{~s}$.
c. $55^{\circ} \mathrm{C}$ for $40 \mathrm{~s}$.
d. $72^{\circ} \mathrm{C}$ for $45 \mathrm{~s}$.
e. Repeat steps b-d 34 times.
f. $72^{\circ} \mathrm{C}$ for $5 \mathrm{~min}$.

4. Prepare restriction endonuclease reaction by adding $10 \mu \mathrm{l}$ of PCR product, $1 \mu \mathrm{l}$ of PflFI (see Subheading 2.1., item 13), $2.5 \mu \mathrm{l}$ of 10× NEBuffer 4 (see Subheading 2.1., item 13) and $11.5 \mu \mathrm{l}$ of $\mathrm{H}_{2} \mathrm{O}$.

5. Incubate reaction at $37^{\circ} \mathrm{C}$ for $3 \mathrm{~h}$.

6. Electrophorese $10 \mu \mathrm{l}$ of digested PCR product on a $2 \%$ ethidium bromide-stained agarose gel by using $5 \mu \mathrm{l}$ of HyperLadder IV (see Subheading 2.1., item 4) size standard. The gel is viewed using a Bio-Rad Gel Doc 1000 transilluminator and Quantity One 4.5.1 software.

7. Digested positive and negative controls are run on each gel to visualize mutant DNA (1015-bp) and wild-type DNA (386- and 629-bp) fragment patterns.

\subsubsection{E200K}

1. Prepare a premix of MegaMix Blue (see Subheading 2.1., item 3) containing primers at $0.5 \mu \mathrm{M}$ sufficient for $25-\mu 1$ reactions on a 96 -well plate. PCR primers are 5'-CTA TGC 
ACT CAT TCA TTA TGC-3' (forward) and 5'-GTT TTC CAG TGC CCA TCA GTG-3'

(reverse).

2. Add $1 \mu \mathrm{l}$ of genomic DNA at $20 \mathrm{ng} / \mu \mathrm{l}$.

3. Thermal cycling is performed on an MJ Research Tetrad 1 PCR machine or similar using the following cycling parameters:
a. $94^{\circ} \mathrm{C}$ for $5 \mathrm{~min}$.
b. $94^{\circ} \mathrm{C}$ for $30 \mathrm{~s}$.
c. $55^{\circ} \mathrm{C}$ for $40 \mathrm{~s}$.
d. $72^{\circ} \mathrm{C}$ for $45 \mathrm{~s}$.
e. Repeat steps b-d 34 times.
f. $72^{\circ} \mathrm{C}$ for $5 \mathrm{~min}$.

4. Prepare restriction endonuclease reaction by adding $10 \mu \mathrm{l}$ of PCR product, $1 \mu \mathrm{l}$ of BsaI (see Subheading 2.1., item 14), $2.5 \mu \mathrm{l}$ of 10× NEBuffer 3 (see Subheading 2.1., item 14), and $11.5 \mu \mathrm{l}$ of $\mathrm{H}_{2} \mathrm{O}$.

5. Incubate reaction at $50^{\circ} \mathrm{C}$ for $3 \mathrm{~h}$.

6. Electrophorese $10 \mu \mathrm{l}$ of digested PCR product on a $2 \%$ ethidium bromide-stained agarose gel by using $5 \mu \mathrm{l}$ of HyperLadder IV (see Subheading 2.1., item 4) size standard and view using a Bio-Rad Gel Doc 1000 transilluminator and Quantity One 4.5.1 software.

7. Digested positive and negative controls are run on each gel to visualize mutant DNA (1015-bp) and wild-type DNA (318- and 697-bp) fragment patterns.

\subsubsection{Characterization of Insertion Mutations}




\subsubsection{Generation of Amplicon to Be Cloned}

1. Prepare a premix of MegaMix Blue (see Subheading 2.1., item 3) containing primers at $0.5 \mu \mathrm{M}$ sufficient for $25-\mu 1$ reactions on a 96 -well plate. PCR primers are $5^{\prime}$-GAC CTG GGC CTC TGC AAG AAG CGC-3' (forward) and 5'-GGC ACT TCC CAG CAT GTA GCC G-3' (reverse). (Note that MegaMix Blue contains an enzyme that has 3-prime terminal adenosine triphosphate transferase activity that ensures that the amplicon has "A" overhangs to anneal to the "T" overhangs of the cloning vector).

2. Add $1 \mu \mathrm{l}$ of genomic DNA at $20 \mathrm{ng} / \mu \mathrm{l}$.

3. Thermal cycling is performed on an MJ Research Tetrad 1 PCR machine or similar using the following cycling parameters:
a. $94^{\circ} \mathrm{C}$ for 5 min.
b. $94^{\circ} \mathrm{C}$ for $30 \mathrm{~s}$.
c. $65^{\circ} \mathrm{C}$ for $30 \mathrm{~s}$.
d. $72^{\circ} \mathrm{C}$ for $1 \mathrm{~min}$.
e. Repeat steps b-d 34 times.
f. $72^{\circ} \mathrm{C}$ for $10 \mathrm{~min}$.

4. Electrophorese $5 \mu \mathrm{l}$ of PCR product on a $2 \%$ ethidium bromide-stained agarose gel by using $5 \mu$ l of HyperLadder IV (see Subheading 2.1., item 15) size standard and view using a Bio-Rad Gel Doc 1000 transilluminator and Quantity One 4.5.1 software. 5. To preserve the "A" overhangs, before cloning, carry out as little manipulation as possible and use fresh product. 


\subsubsection{Ligation and Cloning}

1. Perform TOPO TA cloning as described in the online user manual version $\mathrm{O}, 10$ April 2006 (25-0276). Updates of this protocol are available at www.invitrogen.com. Use Invitrogen cat. no. K4575-01 (see Subheading 2.1., item 15) (TOP10, Chemically Competent E. coli, 20 reactions).

\subsubsection{Analysis and Sequencing of Recombinant Clones}

1. There is no need to miniprep possible positive clones. Pick white and light blue clones (color enhancement can be obtained by leaving the plate at $4^{\circ} \mathrm{C}$ overnight if this is preferred) and inoculate wells of a prewarmed 96-well tissue culture or storage plate containing 150-200 $\mu$ l of LB broth (see Subheading 2.1., item 16) containing the appropriate antibiotic.

2. Incubate at $37^{\circ} \mathrm{C}$ for about $5-6 \mathrm{~h}$ or until the wells are opaque.

3. Transfer 50- $\mu$ l aliquots to a $96-$ well PCR plate.

4. Seal the plate and place on a PCR machine for $10 \mathrm{~min}$ at $99^{\circ} \mathrm{C}$ to lyse the bacteria. Aliquots $(1 \mu \mathrm{l})$ of these crude DNA preparations can then be used to produce amplicons by using the same methods used to produce the original amplicon by simple transfer to a fresh 96-well PCR plate containing the appropriate PCR mix.

5. Electrophorese $5 \mu \mathrm{l}$ of PCR product on a $2 \%$ ethidium bromide-stained agarose gel by using $5 \mu$ of HyperLadder IV (see Subheading 2.1., item 4) size standard. The gel is viewed using a Bio-Rad Gel Doc 1000 transilluminator and Quantity One 4.5.1 software. 6. Amplicons from positive wells can be purified and sequenced according to the automated sequencing protocol for PCR products (see Subheadings 3.1.2.2.-3.1.2.6.). 
7. Amplicons will contain Taq polymerase artefacts preserved in the cloning process. Therefore, at least three clones should be sequenced to obtain a consensus sequence, preferably on both strands.

\subsubsection{Alternative Confirmation of Missense or Stop Mutations using Real-Time PCR}

\subsubsection{P102L}

1. For each reaction, prepare a premix of $10 \mu \mathrm{l}$ of GTXpress Master Mix (see

Subheading 2.1., item 17), $2 \mu$ l each of forward primer, reverse primer, wild-type probe and mutant probe and $1 \mu \mathrm{l}$ of water (Primer stocks at $9 \mu \mathrm{M}$, probe stocks are at $2 \mu \mathrm{M}$ ). Primer and probes are 5'-GGA GGT GGC ACC CAC AGT C-3' (forward primer), 5'GCC ATG TGC TTC ATG TTG GTT-3' (reverse primer), 5'-FAM-CTT ACT CGG CTT GTT C-3' (wild-type probe) and 5'-VIC-CTT ACT CAG CTT GTT CC-3' (mutant probe) (see Subheading 2.1., item 18).

2. Add $1 \mu \mathrm{l}$ of genomic DNA at $20 \mathrm{ng} / \mu \mathrm{l}$. Positive, negative and no-template controls are also run on each plate.

3. Thermal cycling and data capture are performed on a QuantStudio 12K Flex machine (Life Technologies) using a fast 96-well block, choosing genotyping mode and a fast instrument run.

4. On completion of the run, inspecting the allele discrimination plot will show the unknown sample clustering with either the positive controls or the negative controls.

\subsubsection{D178N}


1. For each reaction, prepare a premix of $10 \mu \mathrm{l}$ of GTXpress Master Mix (see

Subheading 2.1., item 17), $2 \mu$ l each of forward primer, reverse primer, wild-type probe and mutant probe and $1 \mu \mathrm{l}$ of water. Primer and probes are 5'-CAG GCC CAT GGA TGA GTA CA-3' (forward primer), 5'-CGT GTG CTG CTT GAT TGT GA-3' (reverse primer), 5'-FAM-TTG ACG CAG TCG TGC A-3' (wild-type probe) and 5'-VIC-TTG ACG CAG TTG TGC A-3’ (mutant probe) (see Subheading 2.1., item 18).

2. Add $1 \mu \mathrm{l}$ of genomic DNA at $20 \mathrm{ng} / \mu \mathrm{l}$. Positive, negative and no-template controls are also run on each plate.

3. Thermal cycling and data capture are performed on a QuantStudio 12K Flex machine (Life Technologies) using a fast 96-well block, choosing genotyping mode and a fast instrument run.

4. On completion of the run, inspecting the allele discrimination plot will show the unknown sample clustering with either the positive controls or the negative controls.

\subsubsection{E200K}

1. For each reaction, prepare a premix of $10 \mu \mathrm{l}$ of GTXpress Master Mix (see

Subheading 2.1., item 17), $2 \mu$ l each of forward primer, reverse primer, wild-type probe and mutant probe and $1 \mu \mathrm{l}$ of water. Primer and probes are 5'-CGG TCA CCA CAA CCA CCA A-3' (forward primer), 5'-CAC GCG CTC CAT CAT CTT AA-3' (reverse primer), 5'-FAM-AAC TTC ACC GAG ACC GA-3' (wild-type probe) and 5'-VIC-AGA ACT TCA CCA AGA CC-3' (mutant probe) (see Subheading 2.1., item 18).

2. Add $1 \mu \mathrm{l}$ of genomic DNA at $20 \mathrm{ng} / \mu \mathrm{l}$. Positive, negative and no-template controls are also run on each plate. 
3. Thermal cycling and data capture are performed on a QuantStudio 12K Flex machine (Life Technologies) using a fast 96-well block, choosing genotyping mode and a fast instrument run.

4. On completion of the run, inspecting the allele discrimination plot will show the unknown sample clustering with either the positive controls or the negative controls.

\subsection{Immunoblotting}

\subsubsection{Biosafety}

1. All procedures are performed within a class 1 microbiological safety cabinet situated within an ACDP level III containment laboratory with strict adherence to local rules of safe working practice. Informed consent for the analysis of samples must be in place before investigation.

2. No unsealed biological material (tissue or derivative sample thereof) is manipulated outside of the class 1 microbiological safety cabinet. Disposable gloves, safety gown, and safety glasses are worn at all times.

3. 1.5-ml screw-top microfuge tubes containing a rubber O-ring are used.

4. Guidelines for decontamination of human prions are available (75). All disposable plasticware (e.g., tubes, tips, and so on) and solutions containing biological material are decontaminated in 50\% (v/v) sodium hypochlorite solution (containing $>20,000 \mathrm{ppm}$ available chlorine prepared in water) for at least $1 \mathrm{~h}$ before disposal of the liquid phase down designated laboratory sinks within the containment laboratory. Sharps (needles and scalpels) are disposed of immediately after use into a sharps bin and autoclaved at $136^{\circ} \mathrm{C}$ for 20 min before incineration. 
5. Decontaminated plasticware is transferred to a sharps bin and autoclaved at $136^{\circ} \mathrm{C}$ for 20 min before incineration.

\subsubsection{Preparation of Tissue Homogenate}

1. Tissue specimens, stored frozen in sealed pots within the ACDP level III containment laboratory, are transferred into a class 1 microbiological safety cabinet and partially thawed and placed on a petri dish.

2. A suitable quantity of tissue is excised using a scalpel and sealed in a disposable plastic pot and weighed. The tissue is then prepared as a $10 \%(\mathrm{w} / \mathrm{v})$ homogenate in Dulbecco's sterile PBS lacking $\mathrm{Ca}^{2+}$ and $\mathrm{Mg}^{2+}$ ions (see Subheading 2.2., item 1). The amount of PBS to add in microliters is equal to 9 times wet weight of tissue in milligrams. This calculation will produce a homogenate very close to a true $10 \%(\mathrm{w} / \mathrm{v})$ ratio without the necessity of having to accurately measure the total volume of tissue in PBS before the homogenization process.

3. Homogenization of brain tissue is achieved by serial passage of tissue through syringe needles of decreasing diameter (needle gauges 19, 21, 23, and 25).

4. Homogenization of peripheral tissue is achieved through the use of glass Duall tissue grinders (see Subheading 2.2., item 2).

5. The homogenate is stored as aliquots in $1.5 \mathrm{ml}$ screw-top microfuge tubes at $-80^{\circ} \mathrm{C}$.

\subsubsection{Proteinase K Digestion and Electrophoresis}

$1.10 \%$ brain homogenate is thawed, thoroughly vortexed, and then centrifuged at $100 \mathrm{~g}$ (800 rpm) for $1 \mathrm{~min}$ in a microfuge (see Note 1). 
2. 20- $\mu$ l aliquots of the resultant supernatant are adjusted to a final concentration of 50 $\mu \mathrm{g} / \mathrm{ml}$ proteinase (see Subheading 2.2., item 3) by addition of $1.05 \mu \mathrm{l}$ of a $1 \mathrm{mg} / \mathrm{ml}$ proteinase K stock solution (see Note 2).

3. Samples are incubated at $37^{\circ} \mathrm{C}$ for $1 \mathrm{~h}$, followed by centrifugation at $16,100 \mathrm{~g}(13,200$ rpm) for 1 min in a microfuge.

4. The digestion is terminated by resuspension of the sample with an equal volume (21 $\mu \mathrm{l}$ ) of $2 \times$ working SDS sample buffer (see Subheading 2.2., item 4) and immediate transfer to a $100^{\circ} \mathrm{C}$ heating block for $10 \mathrm{~min}$.

5. Samples for analysis in the absence of proteinase $\mathrm{K}$ treatment are treated directly with an equal volume of $2 \times$ working SDS sample buffer (see Subheading 2.2., item 4) and heated similarly.

6. All samples are centrifuged at $16,100 \mathrm{~g}(13,200 \mathrm{rpm})$ for $1 \mathrm{~min}$ in a microfuge, thoroughly vortexed, and then recentrifuged $16,100 \mathrm{~g}$ for $1 \mathrm{~min}$ before electrophoresis of the supernatant.

7. $10 \mu \mathrm{l}$ of the supernatant is loaded on an Novex® $16 \%$ Tris-glycine polyacrylamide mini gel (see Subheading 2.2., item 5) (see Note 3). The remainder of the sample can be stored at $-80^{\circ} \mathrm{C}$. Then, $10 \mu \mathrm{l}$ of $1 \times$ working SDS sample buffer (prepared by mixing $2 \times$ working SDS sample buffer with an equal volume of water) should be added in any blank lane. Ten microliters of Seeblue prestained molecular mass markers (see Subheading 2.2., item 6) is used to calibrate the gel.

8. Gels are run at a constant voltage of $200 \mathrm{~V}$ for $80 \mathrm{~min}$ in SDS-PAGE running buffer (see Subheading 2.2., item 7) (see Note 3). 
9. Gels are electroblotted (one gel per XCell II ${ }^{\mathrm{TM}}$ blot module (Novex $\left.{ }^{\circledR}\right)$ ) on to polyvinylidene difluoride membrane (see Subheading 2.2., item 8) in electroblotting buffer (see Subheading 2.2., item 9) at a constant voltage of $35 \mathrm{~V}$ for $2 \mathrm{~h}$ or $15 \mathrm{~V}$ overnight. Immobilon P membrane is soaked for $2 \mathrm{~min}$ in $100 \%$ methanol and then rinsed in electroblotting buffer immediately before use.

\subsubsection{High-Sensitivity Chemiluminescence (ECL)}

1. Blots are blocked with 5\% (w/v) nonfat milk powder in PBST (see Subheading 2.2., item 10) for $1 \mathrm{~h}$ followed by brief rinsing with PBST.

2. Blots are incubated with anti-PrP monoclonal antibody 3F4 (see Subheading 2.2., item 11) at a final concentration of $0.2 \mu \mathrm{g} / \mathrm{ml}$ in PBST containing $0.1 \%(\mathrm{w} / \mathrm{v}$ ) sodium azide for either 90 min or overnight.

3. Blots are washed for a minimum of $30 \mathrm{~min}$ and up to $60 \mathrm{~min}$ with at least six changes of PBST.

4. Blots are incubated for $1 \mathrm{~h}$ with a 1:10,000 dilution of goat anti-mouse IgGphosphatase conjugate (see Subheading 2.2., item 12) in PBST.

5. Blots are washed for a minimum of $30 \mathrm{~min}$ and up to $60 \mathrm{~min}$ with at least six changes of PBST.

6. Blots are washed $2 \times 5$ min with $20 \mathrm{mM}$ Tris, $\mathrm{pH} 9.8$, containing $1 \mathrm{mM} \mathrm{MgCl}$.

7. Blots are developed with chemiluminescent substrate CDP-Star (see Subheading 2.2., item 13) and visualized on Biomax MR film (see Subheading 2.2., item 14) (see Note 4). 


\subsubsection{Standard Enhanced Chemifluorescence (ECF)}

1. Blots are blocked with 5\% (w/v) nonfat milk powder in PBST (see Subheading 2.2., item 10) for $1 \mathrm{~h}$ followed by brief rinsing with PBST.

2. Blots are incubated with anti-PrP monoclonal antibody 3F4 (see Subheading 2.2., item 11) at a final concentration of $0.2 \mu \mathrm{g} / \mathrm{ml}$ in PBST containing $0.1 \%(\mathrm{w} / \mathrm{v}$ ) sodium azide for either 90 min or overnight.

3. Blots are washed for a minimum of $30 \mathrm{~min}$ and up to $60 \mathrm{~min}$ with at least six changes of PBST.

4. Blots are incubated for $1 \mathrm{~h}$ with a 1:5,000 dilution of goat anti-mouse IgG-phosphatase conjugate (see Subheading 2.2., item 12) in PBST.

5. Blots are washed for a minimum of $30 \mathrm{~min}$ and up to $60 \mathrm{~min}$ with at least six changes of PBST.

6. Blots are washed $2 \times 5$ min with $20 \mathrm{mM}$ Tris, $\mathrm{pH} 9.8$, containing $1 \mathrm{mM} \mathrm{MgCl}$.

7. Blots are developed with chemifluorescent substrate AttoPhos (see Subheading 2.2., item 15) and visualized on a Storm 840 PhosphorImager (GE Healthcare, Little Chalfont, Buckinghamshire, UK). PrP glycoforms are quantified with ImageQuaNT software (GE Healthcare) (see Note 4).

\subsubsection{Sodium Phosphotungstic Acid Precipitation}

Methods are adapted from the original procedure of Safar et al. (76) as described by Wadsworth et al. (35). 
1. $10 \%(\mathrm{w} / \mathrm{v})$ homogenates from human brain or peripheral tissues prepared in Dulbecco's PBS lacking $\mathrm{Ca}^{2+}$ and $\mathrm{Mg}^{2+}$ ions (see Subheading 2.2., item 1) are centrifuged at $100 \mathrm{~g}(800 \mathrm{rpm})$ for $1 \mathrm{~min}$ in a microfuge.

2. $500 \mu \mathrm{l}$ of the resultant supernatant is mixed with an equal volume of $4 \%$ (w/v) sodium lauroylsarcosine (see Subheading 2.2., item 16) prepared in Dulbecco's PBS lacking $\mathrm{Ca}^{2+}$ and $\mathrm{Mg}^{2+}$ ions (see Subheading 2.2., item 1) and incubated for $10 \mathrm{~min}$ at $37^{\circ} \mathrm{C}$ with constant agitation.

3. Samples are adjusted to final concentrations of $50 \mathrm{U} / \mathrm{ml}$ Benzonase (see Subheading 2.2., item 17) (add $2 \mu \mathrm{l}$ of $25 \mathrm{U} / \mu 1$ Benzon nuclease, purity 1) and $1 \mathrm{mM} \mathrm{MgCl} 2$ (add 0.5 $\mu \mathrm{l}$ of $2 \mathrm{M} \mathrm{MgCl}_{2}$ prepared in water) and incubated for $30 \mathrm{~min}$ at $37^{\circ} \mathrm{C}$ with constant agitation.

4. Samples are adjusted with $81.3 \mu \mathrm{l}$ of a sodium phosphotungstic acid stock solution (see Subheading 2.2., item 18) to give a final concentration in the sample of $0.3 \%(w / v)$ sodium phosphotungstic acid. This stock solution is pre-warmed to $37^{\circ} \mathrm{C}$ before use, and both the sample and the stock solution should be at $37^{\circ} \mathrm{C}$ upon mixing to avoid formation of insoluble magnesium salts.

5. Samples are incubated at $37^{\circ} \mathrm{C}$ for $30 \mathrm{~min}$ with constant agitation before centrifugation at $16,100 \mathrm{~g}(13,200 \mathrm{rpm})$ for $30 \mathrm{~min}$ in a microfuge. The microfuge rotor can be prewarmed to $37^{\circ} \mathrm{C}$ before use, because this helps to avoid salt precipitation during centrifugation.

6. After careful isolation of the supernatant, the sample is recentrifuged at $16,100 \mathrm{~g}$ $(13,200 \mathrm{rpm})$ for $2 \mathrm{~min}$, and the residual supernatant is discarded. New tops are placed on the microfuge tubes. 
7. Pellets are resuspended to a $20-\mu 1$ final volume with Dulbecco's PBS lacking $\mathrm{Ca}^{2+}$ and $\mathrm{Mg}^{2+}$ ions containing $0.1 \%(\mathrm{w} / \mathrm{v})$ sodium lauroylsarcosine and proteinase $\mathrm{K}$ digested and processed for immunoblotting as described in Subheading, 3.2.3, steps 2-9 (see Note 5).

\subsection{Immunohistochemistry}

\subsubsection{Procurement}

\subsubsection{Biosafety}

For samples suspected to contain infectious prions, all procedures are performed within a class 1 microbiological safety cabinet situated within an ACDP level III containment laboratory with strict adherence to local rules of safe working practice. Informed consent for the analysis of samples must be in place before investigation. Samples are kept in a category III laboratory before decontamination with formic acid. Guidelines for decontamination of human prions are available (75). Liquids that have been in contact with infected samples are decontaminated by mixing with an equal volume of $2 \mathrm{M}$ sodium hydroxide for at least $1 \mathrm{~h}$. For certain reagents, specialist disposal is preferred due to chemical incompatibilities (75).

\subsubsection{Whole Brain, Brain Hemispheres, or Whole Internal Organs}

1. Large specimens of tissue (whole brain, brain hemispheres, whole internal organs) are suspended in $10 \%$ buffered formal-saline (see Subheading 2.3.1., item 1). The volume added should be approximately 5 times the volume of tissue.

2. If there is excess blood within the sample, the $10 \%$ buffered formal-saline should be exchanged until it remains clear. 
3. Tissue is left for up to 3 weeks to ensure adequate fixation and hardening.

4. After fixation, samples of tissue are excised with dimensions suitable for histology cassettes (see Subheading 2.3.1., item 2).

\subsubsection{Small Specimens of Brain or Peripheral Tissues}

1. Smaller pieces of brain (frontal cortex, temporal cortex, parietal cortex, occipital cortex, cerebellum) or samples of other peripheral tissues (tonsil, spleen, lymph nodes, appendix), with dimensions no larger than approximately $3 \mathrm{~cm} \times 3 \mathrm{~cm} \times 1 \mathrm{~cm}$, are commonly provided for investigation.

2. Tissue samples are immersed in approximately 5 volumes of $10 \%$ buffered formalsaline (see Subheading 2.3.1., item 1).

3. If there is excess blood within the sample, the $10 \%$ buffered formal-saline should be exchanged until it remains clear.

4. Fixation of the samples is achieved after 2 days.

5. After fixation, samples of tissue are excised with dimensions suitable for histology cassettes (see Subheading 2.3.1., item 2).

\subsubsection{Prion Deactivation with Formic Acid}

1. All brain tissue must be of a size suitable for processing. Generally, this is considered as the size and thickness of the histology cassettes (see Subheading 2.3.2., item 1). Care must be taken not to overfill the cassettes, because this will result in poor processing and distortion. 
2. After being encased in labeled cassettes, the samples are immersed in $98 \%$ formic acid (see Subheading 2.3.2., item 2) for $1 \mathrm{~h}$.

3. Formic acid is decanted into a waste pot half filled with $2 \mathrm{M}$ sodium hydroxide (see

\section{Subheading 2.3.2., item 3).}

4. Specimens are treated with approximately5 volumes of $10 \%$ buffered formal-saline (see Subheading 2.3.2., item 4) for $1 \mathrm{~h}$.

5. The 10\% buffered formal-saline (see Subheading 2.3.2., item 4) is exchanged at least once to ensure any excess of formic acid has been removed before tissue processing.

6. Samples are removed from the ACDP level III containment laboratory.

7. Samples are placed on a tissue processor in an ACDP level II containment laboratory.

\subsubsection{Tissue Processing}

10\% buffered formal saline (see Subheading 2.3.3., item 1) is an aqueous fixative; therefore, the samples are treated through a series of processing stages before wax embedding. Each stage needs to be of sufficient length to ensure impregnation. The stages are as follows:

1. Dehydration: The samples are taken through a series of industrial methylated spirits (IMS) (see Subheading 2.3.3., item 2) (70, 90, 100\%) to remove water (Table 1).

2. Clearing: The alcohol is replaced by xylene (see Subheading 2.3.3., item 3), a fluid miscible with IMS and paraffin wax (see Subheading 2.3.3., item 4) (Table 1).

3. Impregnation: the xylene is replaced with molten paraffin wax (see Subheading 2.3.3., item 4) (Table 1). 
4. Embedding: The samples are embedded in the desired orientation in molten paraffin wax (see Subheading 2.3.3., item 4). Once the wax has hardened, the samples are ready for sectioning.

\subsubsection{Tissue Sectioning}

1. The microtome (see Subheading 2.3.4., item 1) is set at $8 \mu \mathrm{m}$ for tissue sectioning, although this measure can be varied.

2. The sample block, now in wax, is mounted on to the microtome chuck and serial sections of the sample are taken.

3. Sections are floated out on a water bath set at $40^{\circ} \mathrm{C}$.

4. The sections are mounted on SuperFrost microscope slides (see Subheading 2.3.4., item 2) and left to air dry at $37^{\circ} \mathrm{C}$ for approximately $2 \mathrm{~h}$.

5. Slides are dried at $60^{\circ} \mathrm{C}$ for a minimum of $2 \mathrm{~h}$, after which they are ready to be stained.

6. Tonsil sections require cutting just before staining. Immunoreactivity is markedly reduced if sections are exposed to air for long periods of time.

\subsubsection{Tissue Staining}

\subsubsection{Staining with Hematoxylin and Eosin (H\&E)}

1. Rehydrate the sections by removing paraffin in three changes of xylene (see

Subheading 2.3.5., item 1), followed by sequential washing for 1-2 min with graded alcohol (see Subheading 2.3.5., item 2) $(100 \% \times 2,90 \%$, and $70 \%)$ and final washing in running tap water. 
2. Place the slides in filtered Harris hematoxylin solution (see Subheading 2.3.5., item 3) for $5 \mathrm{~min}$.

3. Wash briefly in running tap water and differentiate in $1 \%$ acid alcohol (see Subheading 2.3.5., item 4) for $30 \mathrm{~s}$.

4. Wash well in running tap water and allow the color to develop. Check microscopically. Nuclei look dark blue, whereas background shows a weak residual hematoxylin coloration.

5. Wash briefly in running water and stain with Eosin Y solution (see Subheading 2.3.5., item 5) for $2-3 \mathrm{~min}$.

6. Wash sections sequentially for $\sim 1-2$ min with water, $70 \%$ ethanol, $90 \%$ ethanol, $100 \%$ ethanol, and xylene.

7. Mount sections in a xylene-based mounting medium, Pertex (see Subheading 2.3.5., item 6) (see Note 6).

\subsubsection{Staining for Glial Fibrillary Acidic Protein (GFAP)}

1. The sections to be stained are placed in plastic racks and paraffin removed, as described in Subheading 3.3.5.1.

2. The slides are placed on the Benchmark XT Staining Machine (see Subheading 2.3.5., item 7) (Ventana Medical Systems) with a 4-min pre-treatment with Protease 1 (see Subheading 2.3.5., item 8).

3. The slides are incubated with a GFAP antibody (see Subheading 2.3.5., item 9) diluted 1:1000 in antibody diluent (see Subheading 2.3.5., item 9). 
4. The slides are stained using the staining kit IViewDAB (see Subheading 2.3.5., item 10) and counterstained using hematoxylin (see Subheading 2.3.5., item 11) and a bluing reagent (see Subheading 2.3.5., item 12).

5. Once the run is finished, the slides are washed in hot soapy water (diluted washing up liquid) and dehydrated through alcohol and xylene.

6. Mount sections in a xylene-based mounting medium, Pertex (see Subheading 2.3.5., item 6) (see Note 7).

\subsubsection{Staining for PrP}

1. The sections to be stained are placed in plastic racks and paraffin removed as described in Subheading 3.3.5.1.

2. The pre-treatment for detection of abnormal PrP deposition is dependent upon the tissue and the length of fixation. For human brain samples that have been fixed for up to $\sim 2$ weeks, the microwave heat retrieval method is preferred. If the brain samples are fixed for longer periods, the pressure cooker method is used. If tonsil or other secondary lymphoid tissue is being examined, the autoclaving heat retrieval method is used.

\subsection{Microwave Method}

3. After removal of paraffin (see Subheading 3.3.5.1.) the slides are placed in 1 liter of Tris-EDTA-citrate buffer (see Subheading 2.3.5., item 13), and then they were placed in a microwave for $25 \mathrm{~min}$ at $800-\mathrm{W}$ power.

4. The slides are washed in running cold tap water for $3 \mathrm{~min}$. 
5. The samples are covered with $98 \%$ formic acid (see Subheading 2.3.5., item 14), incubated for $5 \mathrm{~min}$, and then washed in running cold tap water for $5 \mathrm{~min}$ to remove excess formic acid.

\subsection{Pressure Cooker Method}

6. After removal of paraffin (see Subheading 3.3.5.1.), the slides are placed in a pressure cooker containing 1.5 liters of boiling Tris-EDTA-citrate buffer (see Subheading 2.3.5., item 13) for $5 \mathrm{~min}$ at high pressure and $5 \mathrm{~min}$ at low pressure.

7. Place the slides under running cold water for $5 \mathrm{~min}$ and treat with $98 \%$ formic acid (see Subheading 2.3.5., item 14) for a further $5 \mathrm{~min}$. Wash the slides in running water for 5 min to remove excess formic acid.

\subsection{Autoclaving Heat Retrieval}

8. After removal of paraffin (see Subheading 3.3.5.1.), the slides are placed in an autoclave resistant tub containing 1 liter of citrate buffer (see Subheading 2.3.5., item 15).

9. The tub is covered with aluminium foil and run in an autoclave at $121^{\circ} \mathrm{C}$ for $20 \mathrm{~min}$. Allow autoclave to return to low pressure before removing the tub. Place slides under running cold tap water.

10. Treat with $98 \%$ formic acid (see Subheading 2.3.5., item 14) for a further 5 min. Wash the slides in running water for 5 min to remove excess formic acid.

\subsection{Automated Staining}


11. The monoclonal anti-PrP antibody ICSM35 (see Subheading 2.3.5., item 16) (1 $\mathrm{mg} / \mathrm{ml}$ stock) is used at a 1:1,000 dilution in antibody diluent (see Subheading 2.3.5., item 9).

12. Automated staining is carried out on the Benchmark Staining Machine (see

Subheading 2.3.5., item 7) from Ventana Medical Systems.

13. The slides are subjected to further pre-treatment with Protease 3 (see Subheading 2.3.5., item 17) for 4 min, and then 10 min with Superblock (see Subheading 2.3.5., item 18), a blocking agent. The slides are stained using the staining kit IViewDAB (see Subheading 2.3.5., item 10) and counterstained using hematoxylin (see Subheading 2.3.5., item 11) and a bluing reagent (see Subheading 2.3.5., item 12).

14. Once the staining process is complete, the slides are washed in hot soapy water (diluted washing-up liquid) and dehydrated through alcohol and xylene. They are mounted in a xylene-based mountant as described in Subheading 3.3.5.1. (see Note 8).

\subsection{Manual Staining}

15. Sections are treated to remove paraffin as far as $100 \%$ alcohol (see Subheading 3.3.5.1.).

16. Block endogenous peroxidase activity on the sections by treatment with $2.5 \%(\mathrm{v} / \mathrm{v})$ hydrogen peroxide in methanol (see Subheading 2.3.5., item 19) for $30 \mathrm{~min}$.

17. Wash sections in running tap water for $5 \mathrm{~min}$ and then in purified water for $5 \mathrm{~min}$ and transfer to an appropriate container for autoclaving. Autoclave at $121^{\circ} \mathrm{C}$ for $20 \mathrm{~min}$ in Tris-buffered saline (TBS), pH 7.6 (see Subheading 2.3.5., item 20). 
18. Cool slides in running tap water. Treat the slides in $98 \%$ formic acid (see

Subheading 2.3.5., item 14) for $5 \mathrm{~min}$, wash in running tap water for 5-10 min.

19. Treat sections with $4 \mathrm{M}$ guanidine thiocyanate (see Subheading 2.3.5., item 21) at

$4^{\circ} \mathrm{C}$ for $2 \mathrm{~h}$ and then wash in tap water and transfer to TBS (see Subheading 2.3.5., item 20).

20. Block nonspecific immunoglobulin staining with normal rabbit serum (see

Subheading 2.3.5., item 22) diluted 1:10 in TBS for $30 \mathrm{~min}$. Do not wash off.

21. Apply primary antibody ICSM35 (see Subheading 2.3.5., item 16) $(1 \mathrm{mg} / \mathrm{ml}$ stock)

at 1:1500 dilution in TBS containing 1:100 normal rabbit serum (see Subheading 2.3.5., item 22), overnight at $4^{\circ} \mathrm{C}$.

22. Wash in several changes of TBS.

23. Incubate in biotinylated rabbit anti-mouse immunoglobulins (see Subheading 2.3.5., item 23) 1:200 in TBS for $45 \mathrm{~min}$.

24. Wash in several changes of TBS.

25. Incubate in $A B C$ complex (see Subheading 2.3.5., item 24) for 45 min.

26. Wash in several changes of TBS.

27. Develop in 3,3 diaminobenzidine tetrachloride (see Subheading 2.3.5., item 25 (25 $\mathrm{mg} / 100 \mathrm{ml}$ of TBS) plus $30 \mu \mathrm{l}$ of hydrogen peroxide (see Subheading 2.3.5., item 19) (added just before use) for 5-15 min. Check microscopically. Once chromogen has developed to satisfaction, wash slides in running tap water for $10 \mathrm{~min}$.

28. Counterstain in Harris hematoxylin (see Subheading 2.3.5., item 3) for 3 min. 29. Differentiate in $1 \%$ acid alcohol (see Subheading 2.3.5., item 4) for $5 \mathrm{~s}$. 30. Allow blue coloration to develop in tap water, $5 \mathrm{~min}$. 
31. Dehydrate, clear, and mount as described in Subheading 3.3.5.1. (see Note 8).

\section{Acknowledgements}

We especially thank all patients and their families for generously consenting to use of human tissues in this research and the UK neuropathologists who have kindly helped in providing these tissues. The work was funded by the UK Medical Research Council and Department of Health (England) and was performed under approval from the Institute of Neurology/National Hospital for Neurology and Neurosurgery Local Research Ethics Committee and the code of practice specified in the Human Tissue Authority licence held by UCL Institute of Neurology. Some of the work was undertaken at University College London Hospital NHS Foundation Trust which received a proportion of funding from the Department of Health's NIHR Biomedical Research Centres funding scheme. SB was also supported by the Department of Health's NIHR Biomedical Research Centres funding scheme. We are grateful to R. Young and R Newton for preparation of the figures.

\section{Notes}

1. Whole brain homogenate can be analyzed by identical procedures; however problems of high sample viscosity due to nucleic acid aggregation are often encountered. For processing of $20 \mu \mathrm{l}$ of whole brain homogenate, preincubation with $0.5 \mu \mathrm{l}$ of Benzonase for $10 \mathrm{~min}$ at $20^{\circ} \mathrm{C}$ is recommended before further sample analysis by using appropriately adjusted volumes of subsequent reagents. 
2. $\operatorname{PrP}^{\mathrm{Sc}}$ is covalently indistinguishable from $\operatorname{PrP}^{\mathrm{C}}$, but it can by differentiated from $\operatorname{PrP}^{\mathrm{C}}$ by its partial resistance to proteolysis and its marked insolubility in detergents $(1,77)$. Under conditions in which $\operatorname{PrP}^{\mathrm{C}}$ is completely degraded by the nonspecific protease, proteinase $\mathrm{K}, \mathrm{PrP}^{\mathrm{Sc}}$ in sporadic and acquired forms of human prion disease exists in an aggregated form with the C-terminal two thirds of the protein showing marked resistance to proteolysis, leading to the generation of amino terminally truncated fragments of di-, mono- and nonglycosylated $\operatorname{PrP}(\mathbf{1}, 77)($ Fig. 4).

3. The procedures described here have been optimized for use with Novex ${ }^{\circledR} 16 \%$ acrylamide precast Tris-glycine gels. Variation in the resolution of the system may occur if other gel systems are used or if reagent compositions are varied from those listed here. Optimal resolution of $\operatorname{PrP}^{\mathrm{Sc}}$ fragment size is achieved after electrophoresis for $80 \mathrm{~min}$ at 200 V. For improved separation of PrP glycoforms for densitometry analysis, electrophoresis is performed for $90 \mathrm{~min}$ at $200 \mathrm{~V}$.

4. To date, we have identified four major types of human $\operatorname{PrP}^{\mathrm{Sc}}$ associated with sporadic and acquired human prion diseases that can be differentiated by their fragment size on immunoblots after limited proteinase $\mathrm{K}$ digestion of brain homogenates $(7,9,78,79)$ (Fig. 4). These types can be further classified by the ratio of the three PrP bands seen after protease digestion, corresponding to amino-terminally truncated cleavage products generated from di-, mono-, or nonglycosylated $\operatorname{PrP}^{\mathrm{Sc}}\left(\right.$ Figs. 4, 5). $\mathrm{PrP}^{\mathrm{Sc}}$ types $1-3$ are seen in classical (sporadic or iatrogenic) CJD brain, whereas type $4 \operatorname{PrP}^{\mathrm{Sc}}$ is uniquely seen in vCJD brain $(7,9,78,80)$. An earlier classification of $\operatorname{PrP}^{\mathrm{Sc}}$ types seen in classical CJD described only two banding patterns (81) with $\mathrm{PrP}^{\mathrm{Sc}}$ types 1 and 2 that we describe corresponding with the type 1 pattern of Gambetti and colleagues, and our type 3 
fragment size corresponding to their type 2 pattern $(\mathbf{8 , 8 2})$. Although type $4 \mathrm{PrP}^{\mathrm{Sc}}$ is readily distinguished from the $\operatorname{PrP}^{\mathrm{Sc}}$ types seen in classical CJD by a predominance of the diglycosylated $\mathrm{PrP}$ glycoform, type $4 \mathrm{PrP}^{\mathrm{Sc}}$ also has a distinct proteolytic fragment size (9) (Fig. 4), although this is not recognized by the alternative classification, which designates type $4 \mathrm{PrP}^{\mathrm{Sc}}$ as type $2 \mathrm{~b}(\mathbf{8 2})$. Although proteinase K-resistant PrP fragments of $\sim 21-30 \mathrm{kDa}$ seen in inherited prion disease caused by PRNP P102L, D178N, and E200K mutations have molecular masses similar in size to those seen in classical CJD $(\mathbf{1 0}, 83$ 85), the glycoform ratio is distinct from $\mathrm{PrP}^{\mathrm{Sc}}$ fragments seen in both classical CJD (10, 83-85) and vCJD (10) (Fig. 5). Individuals with these mutations also propagate $\mathrm{PrP}^{\mathrm{Sc}}$

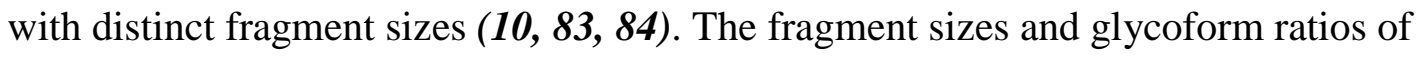
$\mathrm{PrP}^{\mathrm{Sc}}$ seen in 2-, 4-, and 6-OPRI cases are indistinguishable from those of $\mathrm{PrP}^{\mathrm{Sc}}$ seen in classical CJD (10). Importantly detection of $\operatorname{PrP}^{\mathrm{Sc}}$ in the molecular mass range of $~ 21-30$ $\mathrm{kDa}$ is by no means a consistent feature in inherited prion disease; and some cases, in particular those in which amyloid plaques are a prominent feature, show smaller protease resistant PrP fragments of $\sim 7-15 \mathrm{kDa}$ derived from the central portion of $\operatorname{PrP}(\mathbf{1 0}, \mathbf{2 1}, \mathbf{8 3}$, 84, 86-88) (Fig. 4).

5. Sodium phosphotungstic acid precipitation facilitates highly efficient recovery and detection of $\mathrm{PrP}^{\mathrm{Sc}}$ from human tissue homogenate, even when present at levels $10^{4}-10^{5}$ fold lower than found in brain $(35,89)$. This procedure is now the preferred method for diagnostic analysis of tonsil in cases of suspected vCJD, and it should detect $\operatorname{PrP}^{\mathrm{Sc}}$ in tonsil if levels reach $0.1 \%$ or above the maximum levels seen in necropsy vCJD tonsil $(35,90)$. A distinctive $\mathrm{PrP}^{\mathrm{Sc}}$ type, designated type $4 \mathrm{t}$, is seen in both ante-mortem and post-mortem tonsil from patients with vCJD (35, 68) (see Figs. 5 and 7), including 
secondary vCJD infection resulting from blood transfusion (38). Type $4 \mathrm{t} \mathrm{PrP}^{\mathrm{Sc}}$ in tonsil differs in the proportions of the PrP glycoforms from type $4 \mathrm{PrP}^{\mathrm{Sc}}$ seen in vCJD brain $(35,68)$ (see Figs. 5 and 7), implying the superimposition of tissue and strain specific effects on PrP glycosylation $(32,68)$.

6. On H\&E-stained sections nuclei are stained deep blue, and the cytoplasm is stained pink. The cortex and subcortical white matter can be readily distinguished. In the cortex of a patient with prion disease, there may be variable degrees of spongiosis, accompanied astroglial proliferation (Fig. 6). Neuronal loss also may be evident. Although synaptic PrP deposition is generally not recognizable on $\mathrm{H} \& \mathrm{E}$ sections, amyloid PrP plaques as seen in GSS and vCJD may be a prominent feature (Fig. 6). In the cerebellum, spongiosis is generally less evident; however, PrP plaques may be observed particularly in GSS. 7. Reactive astrocytes are readily visualized by GFAP immunohistochemistry. They are characterized by prominent processes (Fig. 6). In the white matter, there may be a diffuse fibrillary gliosis.

8. Abnormal PrP deposition can present with a multitude of intensities, shapes, and distributions. The synaptic pattern is characterized by a fine, dispersed distribution, and it is the predominant pattern of abnormal PrP staining seen in sporadic CJD (Fig. 6). In contrast, PrP amyloid plaques are a predominant feature in GSS, kuru, and vCJD. The histopathologic features of vCJD are remarkably consistent and distinguish it from other human prion diseases with large numbers of PrP-positive amyloid plaques that differ in morphology from the plaques seen in kuru and GSS in that the surrounding tissue takes on a microvacuolated appearance, giving the plaques a florid appearance (Fig. 6). 
Abnormal PrP immunoreactivity in vCJD tonsil $(38,68,90)$ and appendix $(34,91)$ is confined to lymphatic follicles with deposition mainly in dendritic cells (Fig. 7).

\section{Figure legends}

Fig. 1. Pathogenic mutations and polymorphisms in human prion protein. The pathogenic mutations associated with human prion disease are shown above the human PrP coding sequence. These consist of four to twelve OPRI within the octapeptide repeat region between codons 51 and 91, a two OPRD, and various point mutations causing missense or stop codon substitutions. Some of these changes have been observed in individual patients only and should be considered as possible pathogenic mutations that require confirmation. Point mutations are designated by the wild-type amino acid preceding the codon number, followed by the mutant residue, using single-letter amino acid nomenclature ( $\mathrm{X}$ denotes stop). Polymorphic variants are shown below the PrP coding sequence (synonymous changes, green; nonsynonymous changes, blue). Codon 129 and 219 polymorphisms have profound susceptibility, disease-modifying effects, or both. Deletion of one octapeptide repeat is not associated with prion disease in humans.

Fig. 2. $P R N P$ codon 129 polymorphism. Electropherogram traces that illustrate all $P R N P$ codon 129 genotypes in the reverse DNA strand orientation.

Fig. 3. Analysis of $P R N P$ OPRI mutations. Image from agarose gel electrophoresis of PRNP amplicons illustrating the presence of an insertional mutation. Lane 1, HyperLadder IV; lane 2, 1-OPRD control; lane 3, 6 OPRI control; lane 4-8, patient 
samples: lane 6 demonstrates amplification of a heterozygous insertional mutation of 144 base pairs (6-OPRI mutation positive), lanes 4, 5, 7, and 8 are wild-type alleles only; lane 9, no-template control.

Fig. 4. Immunoblot analysis of human PrP. (A) Immunoblot analysis of normal human brain and vCJD brain homogenate before and after treatment with proteinase $\mathrm{K}(\mathrm{PK})$. $\mathrm{PrP}^{\mathrm{C}}$ in both normal and vCJD brain is completely degraded by $\mathrm{PK}$, whereas $\mathrm{PrP}^{\mathrm{Sc}}$ present in vCJD brain shows resistance to proteolytic degradation leading to the generation of amino terminally truncated fragments of di-, mono-, and nonglycosylated PrP. (B) Immunoblot of PK digested brain homogenate with monoclonal antibody 3F4 showing $\operatorname{PrP}^{\mathrm{Sc}}$ types $1-4$ in human brain. Types $1-3 \mathrm{PrP}^{\mathrm{Sc}}$ are seen in the brain of classical forms of CJD (either sporadic or iatrogenic CJD), whereas type $4 \mathrm{PrP}^{\mathrm{Sc}}$ is uniquely seen in vCJD brain. Classification according to Hill et al. (9). (C) Immunoblots of PK digested brain homogenate from cases of inherited prion disease with PRNP mutations showing protease-resistant PrP fragments of $\sim 6-8 \mathrm{kDa}$. The PRNP point mutation is designated above each immunoblot. Immunoblots were developed with antiPrP monoclonal antibody $3 \mathrm{~F} 4$.

Fig. 5. PrP glycoform ratios in human prion disease. PK digestion of brain homogenate and analysis by enhanced chemifluorescence with anti-PrP monoclonal antibody 3F4 enables calculation of the proportions of di-, mono-, and nonglycosylated PrP. The plot shows the protease-resistant $\mathrm{PrP}$ glycoform ratio seen classical CJD ( $\mathrm{PrP}^{\mathrm{Sc}}$ types $\left.1-3\right)$, vCJD ( $\mathrm{PrP}^{\mathrm{Sc}}$ type 4 in brain and type $4 \mathrm{t} \mathrm{PrP}^{\mathrm{Sc}}$ in tonsil) and in cases of inherited prion 
disease. The key shows $\mathrm{PrP}^{\mathrm{Sc}}$ type or mutation and $P R N P$ codon 129 genotype (methionine $[\mathrm{M}]$ and valine $[\mathrm{V}])$. Classification according to Hill et al. $(\mathbf{9 ,}, 10)$. Data points represent the mean relative proportions of di- and mono-PrP as percentage \pm S.E.M. In some cases the error bars were smaller than the symbols used.

Fig. 6. Prion disease pathology. Brain sections from sCJD and vCJD show spongiform neurodegeneration after hematoxylin and eosin staining (H\&E), proliferation of reactive astrocytes after immunohistochemistry using anti-GFAP antibodies (GFAP), and abnormal PrP immunoreactivity after immunohistochemistry using anti-PrP monoclonal antibody ICSM35 (PrP). Abnormal PrP deposition in sCJD most commonly presents as diffuse, synaptic staining, whereas vCJD is distinguished by the presence of florid PrP plaques consisting of a round amyloid core surrounded by a ring of spongiform vacuoles. Bar $=100 \mu \mathrm{m}$. Inset, high-power magnification of a florid PrP plaque.

Fig. 7. Abnormal PrP in vCJD tonsil and appendix. (A) Diagnostic $\operatorname{PrP}^{\mathrm{Sc}}$ analysis of tonsil biopsy tissue. Aliquots $(0.5 \mathrm{ml})$ of $10 \%(\mathrm{w} / \mathrm{v})$ tonsil biopsy homogenate from a patient with suspected vCJD or 10\% normal human tonsil homogenate, either lacking or containing a spike of $50 \mathrm{nl}$ of $10 \%(\mathrm{w} / \mathrm{v})$ vCJD brain homogenate, were subjected to sodium phosphotungstic acid precipitation. Then, $20 \mu \mathrm{l}$ aliquots of whole samples isolated before centrifugation were analyzed in the absence of PK digestion (-) and compared with PK digestion products (+) derived from the entire sodium phosphotungstic acid pellets. The immunoblot was analyzed with anti-PrP monoclonal antibody 3F4 and high-sensitivity enhanced chemiluminescence. (B) PK-digested sodium 
phosphotungstic acid pellet derived from $0.5 \mathrm{ml} 10 \%$ (w/v) appendix homogenate from a patient with neuropathologically confirmed vCJD analyzed by high-sensitivity enhanced chemiluminescence using anti-PrP monoclonal antibody 3F4 (C). Immunohistochemical analysis of vCJD tonsil (i) and appendix (ii) obtained at autopsy. Abnormal PrP immunoreactivity is confined to lymphatic follicles with deposition mainly in dendritic cells. Anti-PrP monoclonal antibody ICSM 35. Bar $=160 \mu \mathrm{m}(\mathrm{C}, \mathrm{i})$ and $100 \mu \mathrm{m}(\mathrm{C}, \mathrm{ii})$. Insets, high-power magnification of PrP deposits. 
Table 1

Protocol for overnight processing of tissue samples for immunohistochemistry

\begin{tabular}{|l|l|l|}
\hline Solution & Time (min) & Temperature \\
\hline $10 \%$ buffered formal-saline & 30 & Ambient \\
\hline IMS 70\% & 75 & Ambient \\
\hline IMS 70\% & 75 & Ambient \\
\hline IMS 70\% & 75 & Ambient \\
\hline IMS 90\% & 60 & Ambient \\
\hline IMS 90\% & 60 & Ambient \\
\hline IMS 100\% & 75 & Ambient \\
\hline IMS 100\% & 75 & Ambient \\
\hline Xylene & 75 & Ambient \\
\hline Xylene & 75 & Ambient \\
\hline Molten paraffin wax & 50 & $60^{\circ} \mathrm{C}$ \\
\hline Molten paraffin wax & 50 & $60^{\circ} \mathrm{C}$ \\
\hline Molten paraffin wax & 50 & $60^{\circ} \mathrm{C}$ \\
\hline Molten paraffin wax & 50 & $60^{\circ} \mathrm{C}$ \\
\hline
\end{tabular}




\section{References}

1. Prusiner S.B. (1998) Prions. Proc Natl Acad Sci USA 95, 13363-13383.

2. Collinge J. (2001) Prion diseases of humans and animals: their causes and molecular basis. Anпu Rev Neurosci 24, 519-550.

3. Collinge J. (2005) Molecular neurology of prion disease. J Neurol Neurosurg Psychiatry 76, 906-919.

4. Wadsworth J.D., Collinge J. (2010) Molecular pathology of human prion disease. Acta Neuropathol 121, 69-77.

5. Collinge J., Clarke A. (2007) A general model of prion strains and their pathogenicity. Science 318, 930-936.

6. Telling G.C., Parchi P., DeArmond S.J. et al. (1996) Evidence for the conformation of the pathologic isoform of the prion protein enciphering and propagating prion diversity. Science 274, 2079-2082.

7. Collinge J., Sidle K.C., Meads J. et al. (1996) Molecular analysis of prion strain variation and the aetiology of 'new variant' CJD. Nature 383, 685-690.

8. Parchi P., Giese A., Capellari S. et al. (1999) Classification of sporadic Creutzfeldt-Jakob Disease based on molecular and phenotypic analysis of 300 subjects. Ann Neurol 46, 224-233.

9. Hill A.F., Joiner S., Wadsworth J.D. et al. (2003) Molecular classification of sporadic Creutzfeldt-Jakob disease. Brain 126, 1333-1346.

10. Hill A.F., Joiner S., Beck J. et al. (2006) Distinct glycoform ratios of protease resistant prion protein associated with PRNP point mutations. Brain 129, 676685.

11. Safar J.G. (2012) Molecular pathogenesis of sporadic prion diseases in man. Prion 6, 108-115.

12. Puoti G., Bizzi A., Forloni G. et al. (2012) Sporadic human prion diseases: molecular insights and diagnosis. Lancet Neurol 11, 618-628.

13. Lloyd S., Onwuazor O.N., Beck J. et al. (2001) Identification of multiple quantitative trait loci linked to prion disease incubation period in mice. Proc Natl Acad Sci USA 98, 6279-6283.

14. Asante E.A., Linehan J, Desbruslais M. et al. (2002) BSE prions propagate as either variant CJD-like or sporadic CJD-like prion strains in transgenic mice expressing human prion protein. EMBO J 21, 6358-6366. 
15. Lloyd S.E., Mead S., Collinge J. (2013) Genetics of prion diseases. Curr Op Genet Dev 23, 345-351.

16. Collinge J (1997) Human prion diseases and bovine spongiform encephalopathy (BSE). Hum Mol Gen 6, 1699-1705.

17. Collinge J and Palmer.M.S. (1997) Prion Diseases. Oxford University Press, Oxford.

18. Beck J.A., Poulter M., Campbell T.A. et al. (2010) PRNP allelic series from 19 years of prion protein gene sequencing at the MRC Prion Unit. Hum Mutat 31, E1551-E1563.

19. Wadsworth J.D., Hill A.F., Beck J. et al. (2003) Molecular and clinical classification of human prion disease. Brit Med Bull 66, 241-254.

20. Collins S.J., Sanchez-Juan P., Masters C.L. et al. (2006) Determinants of diagnostic investigation sensitivities across the clinical spectrum of sporadic Creutzfeldt-Jakob disease. Brain 129, 2278-2287.

21. Kovacs G.G., Trabattoni G., Hainfellner J.A. et al. (2002) Mutations of the prion protein gene phenotypic spectrum. J Neurol 249, 1567-1582.

22. Mead S. (2006) Prion disease genetics. Eur J Hum Genet 14, 273-281.

23. Brown P., Preece M.A., Will R.G. (1992) "Friendly fire" in medicine: hormones, homografts, and Creutzfeldt-Jakob disease. Lancet 340, 24-27.

24. Brown P., Preece M, Brandel J.P. et al. (2000) Iatrogenic Creutzfeldt-Jakob disease at the millennium. Neurology 55, 1075-1081.

25. Brown P., Brandel J.P., Sato T. et al. (2012) Iatrogenic Creutzfeldt-Jakob disease, final assessment. Emerg Infect Dis 18, 901-907.

26. Alpers MP (1987) in Prions: Novel infectious pathogens causing scrapie and Creutzfeldt-Jakob disease. (Prusiner, S. B. and McKinley, M. P., Eds.) pp 451465, Academic Press, San Diego.

27. Mead S., Stumpf M.P., Whitfield J. et al. (2003) Balancing selection at the prion protein gene consistent with prehistoric kuru-like epidemics. Science 300, 640643.

28. Collinge J., Whitfield J., McKintosh E. et al. (2006) Kuru in the 21st century--an acquired human prion disease with very long incubation periods. Lancet $\mathbf{3 6 7}$, 2068-2074.

29. Will R.G., Ironside J.W., Zeidler M. et al. (1996) A new variant of CreutzfeldtJakob disease in the UK. Lancet 347, 921-925. 
30. Hill A.F., Desbruslais M., Joiner S. et al. (1997) The same prion strain causes vCJD and BSE. Nature 389, 448-450.

31. Bruce M.E., Will R.G., Ironside J.W. et al. (1997) Transmissions to mice indicate that 'new variant' CJD is caused by the BSE agent. Nature 389, 498-501.

32. Collinge J. (1999) Variant Creutzfeldt-Jakob disease. Lancet 354, 317-323.

33. Wadsworth J.D., Collinge J. (2007) Update on human prion disease. Biochim Biophys Acta 1772, 598-609.

34. Gill O.N., Spencer Y., Richard-Loendt A. et al. (2013) Prevalent abnormal prion protein in human appendixes after bovine spongiform encephalopathy epizootic: large scale survey. BMJ 347, f5675.

35. Wadsworth J.D., Joiner S., Hill A.F. et al. (2001) Tissue distribution of protease resistant prion protein in variant CJD using a highly sensitive immuno-blotting assay. Lancet 358, 171-180.

36. Llewelyn C.A., Hewitt P.E., Knight R.S. et al. (2004) Possible transmission of variant Creutzfeldt-Jakob disease by blood transfusion. Lancet 363, 417-421.

37. Peden A.H., Head M.W., Ritchie D.L. et al. (2004) Preclinical vCJD after blood transfusion in a PRNP codon 129 heterozygous patient. Lancet 364, 527-529.

38. Wroe S.J., Pal S, Siddique D. et al. (2006) Clinical presentation and pre-mortem diagnosis of variant Creutzfeldt-Jakob disease associated with blood transfusion: a case report. Lancet 368, 2061-2067.

39. Wadsworth J.D., Joiner S., Fox K. et al. (2007) Prion infectivity in variant Creutzfeldt-Jakob disease rectum. Gut 56, 90-94.

40. Collinge J., Palmer M.S., Dryden A.J. (1991) Genetic predisposition to iatrogenic Creutzfeldt-Jakob disease. Lancet 337, 1441-1442.

41. Palmer M.S., Dryden A.J., Hughes J.T. et al. (1991) Homozygous prion protein genotype predisposes to sporadic Creutzfeldt-Jakob disease. Nature 352, 340-342.

42. Windl O., Dempster M., Estibeiro J.P. et al. (1996) Genetic basis of CreutzfeldtJakob disease in the United Kingom: a systematic analysis of predisposing mutations and allelic variation in the PRNP gene. Hum Genet 98, 259-264.

43. Lee H.S., Brown P., Cervenáková L. et al. (2001) Increased susceptibility to Kuru of carriers of the PRNP 129 methionine/methionine genotype. J Infect Dis 183, 192-196. 
44. Mead S., Poulter M., Uphill J. et al. (2009) Genetic risk factors for variant Creutzfeldt-Jakob disease: a genome-wide association study. Lancet Neurol 8, 5766.

45. Wadsworth J.D., Asante E.A., Desbruslais M. et al. (2004) Human prion protein with valine 129 prevents expression of variant CJD phenotype. Science 306, 1793-1796.

46. Wadsworth J.D., Asante E.A., Collinge J. (2010) Contribution of transgenic models to understanding human prion disease. Neuropathol Appl Neurobiol 36, 576-597.

47. Kaski D., Mead S., Hyare H. et al. (2009) Variant CJD in an individual heterozygous for PRNP codon 129. Lancet 374, 2128.

48. Collinge J., Harding A.E., Owen F. et al. (1989) Diagnosis of GerstmannStraussler syndrome in familial dementia with prion protein gene analysis. Lancet 2, 15-17.

49. Collinge J., Owen F., Poulter M. et al. (1990) Prion dementia without characteristic pathology. Lancet 336, 7-9.

50. Collinge J., Brown J., Hardy J. et al. (1992) Inherited prion disease with 144 base pair gene insertion: II: Clinical and pathological features. Brain 115, 687-710.

51. Mallucci G., Campbell T.A., Dickinson A. et al. (1999) Inherited prion disease with an alanine to valine mutation at codon 117 in the prion protein gene. Brain 122, 1823-1837.

52. Mead S., Poulter M., Beck J. et al. (2006) Inherited prion disease with six octapeptide repeat insertional mutation--molecular analysis of phenotypic heterogeneity. Brain 129, 2297-2317.

53. World Health Organisation. (2003) WHO manual for surveillance of human transmissible spongiform encephalopathies.

http://www.who.int/bloodproducts/TSE-manual2003.pdf.

54. Collinge J., Poulter M., Davis M.B. et al. (1991) Presymptomatic detection or exclusion of prion protein gene defects in families with inherited prion diseases. Am J Hum Genet 49, 1351-1354.

55. Owen J., Beck J., Campbell T. et al. (2014) Predictive testing for inherited prion disease: report of 22 years experience. Eur J Hum Genet Apr 9. doi:

10.1038/ejhg.2014.42.

56. Mead S., Gandhi S., Beck J. et al. (2013) A novel prion disease associated with diarrhea and autonomic neuropathy. N Engl J Med 369, 1904-1914. 
57. Zerr I., Kallenberg K., Summers D.M. et al. (2009) Updated clinical diagnostic criteria for sporadic Creutzfeldt-Jakob disease. Brain 132, 2659-2668.

58. Hyare H., Thornton J., Stevens J. et al. (2010) High-b-value diffusion MR imaging and basal nuclei apparent diffusion coefficient measurements in variant and sporadic Creutzfeldt-Jakob disease. AJNR Am J Neuroradiol 31, 521-526.

59. Carswell C., Thompson A., Lukic A. et al. MRI findings are often missed in the diagnosis of Creutzfeldt-Jakob disease. BMC Neurol 12, 153. 2012.

60. McGuire L.I., Peden A.H., Orru C.D. et al. (2012) Real time quaking-induced conversion analysis of cerebrospinal fluid in sporadic Creutzfeldt-Jakob disease. Ann Neurol 72, 278-285.

61. Atarashi R., Satoh K., Sano K. et al. (2011) Ultrasensitive human prion detection in cerebrospinal fluid by real-time quaking-induced conversion. Nat Med 17, 175178.

62. Budka H., Aguzzi A., Brown P. et al. (1995) Neuropathological diagnostic criteria for Creutzfeldt-Jakob disease (CJD) and other human spongiform encephalopathies (Prion diseases). Brain Pathol 5, 459-466.

63. Budka H. (2003) Neuropathology of prion diseases. Br Med Bull 66, 121-130.

64. Brandner S. (2013) Prion diseases. In: Ellison D., Love S., Chimelli L., Harding B.N., Lowe J.S., Vinters H.V., Brandner S., Yong W.H. (eds) Neuropathology. A reference text of CNS pathology $3^{\text {rd }}$ edition. Elseivier Mosby. pp 659-676.

65. Brandner S., Whitfield J., Boone K. et al. (2008) Central and peripheral pathology of kuru: pathological analysis of a recent case and comparison with other forms of human prion disease. Philos Trans R Soc Lond B Biol Sci 363, 3755-3763.

66. Hainfellner J.A., Brantner-Inthaler S., Cervenáková L. et al. (1995) The original Gerstmann-Straussler-Scheinker family of Austria: Divergent clinicopathological phenotypes but constant PrP genotype. Brain Pathol 5, 201-211.

67. Ironside J.W., Head M.W. (2004) Neuropathology and molecular biology of variant Creutzfeldt-Jakob disease. Curr Top Microbiol Immunol 284, 133-159.

68. Hill A.F., Butterworth R.J., Joiner S. et al. (1999) Investigation of variant Creutzfeldt-Jakob disease and other human prion diseases with tonsil biopsy samples. Lancet 353, 183-189.

69. Glatzel M., Abela E., Maissen M. et al. (2003) Extraneural pathologic prion protein in sporadic Creutzfeldt-Jakob disease. N Engl J Med 349, 1812-1820. 
70. Hilton D.A., Sutak J., Smith M.E. et al. (2004) Specificity of lymphoreticular accumulation of prion protein for variant Creutzfeldt-Jakob disease. J Clin Pathol 57, 300-302.

71. Head M.W., Ritchie D., Smith N. et al. (2004) Peripheral tissue involvement in sporadic, iatrogenic, and variant Creutzfeldt-Jakob disease: an immunohistochemical, quantitative, and biochemical study. Am J Pathol 164, 143-153.

72. Joiner S, Linehan J, Brandner S et al. (2005) High levels of disease related prion protein in the ileum in variant Creutzfeldt-Jakob disease. Gut 54, 1506-1508.

73. Mead S., Wadsworth J.D., Porter M.C. et al. (2014) Variant Creutzfeldt-Jakob disease with extremely low lymphoreticular deposition of prion protein. JAMA Neurol 71, 340-343.

74. Wadsworth J.D., Powell C., Beck J.A. et al. (2008) Molecular diagnosis of human prion disease. Methods Mol Biol 459, 197-227.

75. Advisory Committee on Dangerous Pathogens' Transmissible Spongiform Encephalopathy (ACDP TSE) Risk Management Subgroup (2012). Prevention of CJD and vCJD. UK Department of Health. https://www.gov.uk/government/publications/guidance-from-the-acdp-tse-riskmanagement-subgroup-formerly-tse-working-group.

76. Safar J., Wille H., Itri V. et al. (1998) Eight prion strains have $\mathrm{PrP}^{\mathrm{Sc}}$ molecules with different conformations. Nat Med 4, 1157-1165.

77. Riesner D. (2003) Biochemistry and structure of $\operatorname{PrP}(\mathrm{C})$ and $\operatorname{PrP}(\mathrm{Sc})$. Br Med Bull 66, 21-33.

78. Wadsworth J.D., Hill A.F., Joiner S. et al. (1999) Strain-specific prion-protein conformation determined by metal ions. Nat Cell Biol 1, 55-59.

79. Wadsworth J.D., Joiner S., Linehan J.M. et al. (2008) Kuru prions and sporadic Creutzfeldt-Jakob disease prions have equivalent transmission properties in transgenic and wild-type mice. Proc Natl Acad Sci USA 105, 3885-3890.

80. Wadsworth J.D., Joiner S., Linehan J.M. et al. (2008) Review. The origin of the prion agent of kuru: molecular and biological strain typing. Philos Trans $R$ Soc Lond B Biol Sci 363, 3747-3753.

81. Parchi P., Castellani R., Capellari S. et al. (1996) Molecular basis of phenotypic variability in sporadic Creutzfeldt-Jakob disease. Ann Neurol 39, 767-778.

82. Parchi P., Capellari S., Chen S.G. et al. (1997) Typing prion isoforms. Nature 386, 232-233. 
83. Piccardo P., Dlouhy S.R., Lievens P.M.J. et al. (1998) Phenotypic variability of Gerstmann-Straussler-Scheinker disease is associated with prion protein heterogeneity. J Neuropathol Exp Neurol 57, 979-988.

84. Parchi P., Chen S.G., Brown P. et al. (1998) Different patterns of truncated prion protein fragments correlate with distinct phenotypes in P102L GerstmannSträussler-Scheinker disease. Proc Natl Acad Sci USA 95, 8322-8327.

85. Furukawa H., Doh-ura K., Kikuchi H. et al. (1998) A comparative study of abnormal prion protein isoforms between Gerstmann-Sträussler-Scheinker syndrome and Creutzfeldt-Jakob disease. J Neurol Sci 158, 71-75.

86. Piccardo P., Liepnieks J.J., William A. et al. (2001) Prion proteins with different conformations accumulate in Geustmann-Straussler-Scheinker disease caused by A117V and F198S mutations. Am J Pathol 158, 2201-2207.

87. Tagliavini F., Lievens P.M.J., Tranchant C. et al. (2001) A 7-kDa prion protein (PrP) fragment, an integral component of the PrP region required for infectivity, is the major amyloid protein in Gerstmann-Straussler-Scheinker disease A117V. $J$ Biol Chem 276, 6009-6015.

88. Wadsworth J.D., Joiner S., Linehan J. et al. (2006) Phenotypic heterogeneity in inherited prion disease (P102L) is associated with differential propagation of protease-resistant wild-type and mutant prion protein. Brain 129, 1557-1569.

89. Safar J.G., Geschwind M.D., Deering C. et al. (2005) Diagnosis of human prion disease. Proc Natl Acad Sci USA 102, 3501-3506.

90. Frosh A., Smith L.C., Jackson C.J. et al. (2004) Analysis of 2000 consecutive UK tonsillectomy specimens for disease-related prion protein. Lancet 364, 1260-1262.

91. Joiner S, Linehan J, Brandner S et al. (2002) Irregular presence of abnormal prion protein in appendix in variant Creutzfeldt-Jakob disease. J Neurol Neurosurg Psych 73, 597-598. 